\title{
Eğitimde Ölçme ve Değerlendirme Kongrelerinde Sunulan Bildirilerin Doküman Analizi Yöntemi ile İncelenmesi*
}

\section{The Investigation of the Papers Presented in Measurement and Evaluation in Education and Psychology Congresses with Document Analysis}

\author{
Mahmut Sami KOYUNCU ** Mehmet ŞATA *** İsmail KARAKAYA ****
}

$\ddot{O} \mathbf{z}$

Bu araştırmanın amacı Türkiye'de Eğitimde ve Psikolojide Ölçme ve Değerlendirme (EPOD) Kongrelerinde sunulan bildirilerin eğilimlerinin nasıl olduğunun belirlenmesidir. Bu kapsamda 2008, 2010, 2012 ve 2014 yıllarında Eğitimde ve Psikolojide Ölçme ve Değerlendirme Kongrelerinde sunulmuş olan bildirilerin konu temaları, anahtar kelimeleri, yazarların kurumları ve unvanları, araştırma türü, araştırma modeli/deseni, örneklem büyüklüğ̈̈, kullanılan veri türü ve veri toplama aracı incelenmiştir. Bu araștırma, Eğitimde ve Psikolojide Ölçme ve Değerlendirme Kongresinde yapılan çalışmaların eğilimlerinin nasıl olduğunun betimlenmesi ve var olan durumun yorumlanması amaçlandığı için, araştırma deseni nitel araştırma türlerinden durum çalışmasıdır. Veri toplama yöntemi olarak doküman analizi kullanılmıştır. EPOD kongrelerinde sunulan bildirilerin genel olarak "Ölçek Geliştirme ve Uyarlama" , "Eğitim araştırmalarında kullanılan istatistiksel yönelimler" ve "Geniş ölçekli sınavlar, seçme ve yerleştirme sınavları, yüksek riskli sınavlar" konu temalarında yoğunlaştığı belirlenmiştir. "ÖSYM Uygulamaları" ve "Etik" temalarında çok fazla çalışma yapılmadığı belirlenmiştir. Sunulan bildiri türlerinin daha çok nicel araştırma olduğu, buna bağlı olarak tarama ve betimsel araştırma modellerinin kullanıldığı belirlenmiştir. Bildirilerde en çok "ölçme ve değerlendirme", "güvenirlik", "geçerlik" ve anahtar kelimelerinin kullanıldığı tespit edilmiştir.

Anahtar Kelimeler: Bildiri, doküman analizi, EPOD, ölçme ve değerlendirme.

\begin{abstract}
This study aims to determine the trends of the papers presented in Measurement and Evaluation in Education and Psychology (MEEP) Congresses in Turkey. For that purpose, authors` title and where they work, the subjects, key words, research methods, sample size, data type and data collection tool of the papers presented in MEEP Congresses in 2008, 2010, 2012 and 2014 were investigated. In the study, since describing how the trends in the papers presented orally in MEEP congresses and interpreting the existing situation are aimed, the case study which is one of the qualitative research designs was selected as a research design. Data analysis was done using document analysis. The subjects of the papers were generally centered on the following topics: "Scale Development and Implementation", "statistics used in educational research", "standardized tests, selection and placement tests, high-stakes tests". However, "student selection and placement center's implementations" and "ethics" are the subjects that were studied rarely. It is determined that the presented papers were generally in quantitative research methods, especially survey and descriptive research models were used. It is also determined that the most frequently used key words were reliability, validity and measurement and evaluation in these papers.
\end{abstract}

Keywords: Papers, document analysis, MEEP, measurement and evaluation.

\footnotetext{
*Bu çalışma V. Eğitimde ve Psikolojide Ölçme ve Değerlendirme Kongresi’nde (1-3 Eylül 2016, Antalya) sözlü bildiri olarak sunulmuştur.

** Arş. Gör., Gazi Üniversitesi, Gazi Eğitim Fakültesi, Ankara-Türkiye, e-posta: ms koyuncu@ @otmail.com, ORCID ID: https://orcid.org/0000-0002-6651-4851

*** Arş. Gör., Ağrı İbrahim Çeçen Üniversitesi, Eğitim Fakültesi, Ağrı-Türkiye, e-posta: mehmetwsata@gmail.com, ORCID ID: https://orcid.org/0000-0003-2683-4997

**** Doç. Dr., Gazi Üniversitesi, Gazi Eğitim Fakültesi, Ankara-Türkiye, e-posta: ikarakaya2002@gmail.com, ORCID ID: https://orcid.org/0000-0003-4308-6919
} 


\section{GíRiş}

Eğitim sisteminin temel ögeleri arasında yer alan öğrenme sürecinin en genel amacı, eğitimin tanımında yer alan istendik davranışları öğrencilere kazandırmaktır. Öğrenme sürecinde veya sonunda öğrencinin akademik başarı düzeyini belirlemek ve bu düzeyin istenilen oranda olup olmadığına karar vermek için ölçme ve değerlendirme büyük öneme sahiptir (Bayram, 2011). Ölçme ve değerlendirme etkinliği ile eğitim sistemin kontrolü sağlanmakta ve ilgili kişilere gerekli geri bildirim verilebilmektedir.

Ölçme, ölçülen niteliklerin aralarındaki büyüklük ve küçüklük gibi ilişkileri koruyarak bu niteliklerin say1 ve sembollerle ifade edilmesidir (Tan, 2012). Genel anlamda ölçme, herhangi bir niteliği, o niteliğe uygun araçlarla gözlemek ve sonucu araca uygun bir birimle ifade etmektir. Değerlendirme ise Tan (2012)'a göre ölçümlerin ölçüt veya ölçütlerle kıyaslanarak bir karara varma işidir. Bu süreç içerisinde, bireylerin davranışlarındaki değişimin ölçülmesi ve ölçme sonuçlarının değerlendirilmesi bireylerin gelişim düzeylerini belirlemek açısından önem kazanmaktadır. Değerlendirme ile öğrencilerin öğrenme süreçleri izlenerek gerektiğinde kullanılan etkinlikler, yöntemler ve teknikler değiştirilmelidir (Demirel ve Şahinel, 2006).

Öğretme-öğrenme sürecinin önemli değişkenlerinden biri de yapılan ölçme-değerlendirme etkinlikleridir. Öğretim faaliyetlerinin etkililiğinin belirlenmesi süreç içerisinde yapılan çeşitli ölçme-değerlendirme çalışmaları ile belirlenir. Eğitim ortamında bir öğrencinin güçlü ya da zayıf yanlarının ya da öğrenme eksikliklerinin belirlenmesi; sınıfın bir ders ya da üniteyle ilgili olarak hangi konuları öğrenemediği, hangi davranışlarının geliştirilmesi gerektiği; sınıftaki çeşitli gruplar arasında (kız-erkek gibi) çeşitli değişkenler açısından fark olup olmadığı; sınıf düzeyindeki gerekli kazanımların kazanılıp kazanılmadığı ve başarı oranları; öğrencilerin tek tek veya sınıf olarak duyuşsal özelliklerinin durumu ve süreç içindeki değişimi; sınıflar arası başarı, okulun hedeflerine ulaş1lıp ulaşılmadığının belirlenmesi gibi durumlarda ölçme ve değerlendirme gereklidir (Erkuş, 2014).

Doküman analizi çoğunlukla diğer araştırma yöntemlerini tamamlayıcı nitelikte iken, aynı zamanda tek başına bir yöntem olarak da kullanılabilmektedir. Doküman analizi hem basılı hem de elektronik belgeleri gözden geçirmek ve değerlendirmek için sistematik bir prosedürdür (Bowen, 2009). O’Leary (2017) ise doküman analizini birincil araştırma verisi kaynağı olarak çeşitli yazılı metin biçimlerinin toplanması, incelenmesi, sorgulanması ve analiz edilmesini amaçlayan bir araştırma aracı olarak açıklamaktadır.

Dokümanlar, bir araştırma girişiminin bir parçası olarak çeşitli amaçlara hizmet edebilirler. Belgesel materyalin beş özel fonksiyonunu vardır. İlk olarak dokümanlar araştırmada katılımcıların içinde bulunduğu bağlam hakkında veri sağlayabilir. Belgeler, geçmiş olaylara tanıklık ederek, olayların arka plan bilgisini ve tarihsel iç görüsünü sağlayabilirler. Bu tür bilgiler, araştırmacıların çok özel konuların tarihsel köklerini anlamasına yardımcı olabilir ve şu anda incelenmekte olan olaylara etki eden koşulları gösterebilirler. İkinci olarak, belgelerde yer alan bilgiler, sorulması gereken bazı sorulara ve araştırmanın bir parçası olarak gözlemlenmesi gereken durumlara işaret edebilir. Üçüncü olarak, dokümanlar ek araştırma verileri sağlarlar. Dokümanlardan elde edilen bilgiler, bir veri tabanı için değerli ek bilgiler sağlayabilir. Dördüncüsü, dokümanlar değişimi ve gelişimi izlemenin bir yolunu sağlarlar. Belirli bir belgeye ait çeşitli taslaklara erişilebildiğinde, araştırmacı değişiklikleri belirlemek için bunları karşılaştırabilir. Beşinci olarak ise, dokümanlar, bulguları doğrulamak veya diğer kaynaklardan elde edilen kanıtları doğrulamak için bir yol olarak kullanılmaktadır. Özetle, dokümanlar arka plan ve içerik, sorulacak ek sorular, ek veriler ve diğer veri kaynaklarından elde edilen bulguların doğrulanmasını sağlar (Bowen, 2009).

Doküman analizinin avantajları ve sınırlılıkları bulunmaktadır. Doküman analizinin avantajlarına bakıldığında etkili bir yöntem olduğu görülmektedir. Doküman analizi, diğer araştırma yöntemlerinden daha az zaman almaktadır ve bu nedenle daha verimli olmaktadır. Kısacası, veri toplama yerine veri seçimi gerektirmektedir. İkinci avantajı ise kullanılabilirliktir. Yani, birçok belge, özellikle İnternet'in ortaya çıkmasından bu yana kamusal alanda olup, yazarların izni olmadan edinilebilmesidir. Bu doküman analizini nitel araştırmacılar için cazip bir seçenek haline 
getirmektedir. Diğer bir avantajı da maliyet etkililiğidir. Yani, doküman analizi, diğer araştırma yöntemlerinden daha az maliyetlidir ve yeni verilerin toplanması mümkün olmadığında genellikle tercih edilen yöntemlerden biridir. Veriler (belgelerde) zaten toplanmıştır; geriye kalan ise, değerlendirilecek belgelerin içeriği ve kalitesidir. Diğer bir avantajı ise kararlılığıdır. Başka bir değişle araştırmacı tarafindan birden çok kez okunabilmekte ve incelenebilmektedir. Ayrıca araştırma sürecinde değişmeden kalır ve araştırmacının etkisi yoktur (Bowen, 2009).

Doküman analizinin avantajlarının yanında bazı sınırlılıkları da mevcuttur. Bunlardan birincisi ayrıntının yeterince verilmemiş olabilmesidir. Başka bir değişle, dokümanlar araştırmadan ziyade başka amaçlara hizmet etmek için oluşturulmaktadır; yani bunlar bir araştırma gündeminden bağımsız olarak oluşturulmuştur. Sonuç olarak, genellikle bir araştırma sorusuna cevap vermek için yeterli ayrıntı sağlayamayabilirler. İkinci sınırlılığı ise ulaşılabilirliktir. Yani, belgelere erişim kasıtlı olarak engellenmiş olabilir. Diğer bir sınırlılı̆̆ ise önyargılı seçiciliktir. Belgelerin eksik bir şekilde toplanması 'önyargılı seçiciliği' göstermektedir (Yin, 1994).

Son yıllarda dergilerde yayımlanan makalelerin ve araştırma raporlarının metodolojisinin bir parçası olan doküman analizi sayısında bir artış olmuştur. Alan yazına bakıldığında eğitim alanında yapılan tezlerin ve makalelerin incelendiği çalışmaların var olduğu (Erdem, 2011; Küçükoğlu ve Ozan, 2013; Tavşanc1l, vd., 2010; Yaşar ve Papatğa, 2015) görülmektedir. Eğitim bilimlerinin alt alanı olan eğitimde ölçme ve değerlendirme alanında doküman analizi yöntemi kullanılarak yüksek lisans ve doktora tez çalışmalarının incelendiği araştırmaların (Ayva, Ceyhan ve Doğan, 2015; Şenyurt ve Özkan, 2017) var olduğu, ayrıca ölçme ve değerlendirme ile ilişkili olan ölçek geliştirme ve uyarlama ile ilgili makalelerin incelendiği araştırmaların (Acar-Güvendir ve Özer-Özkan, 2015; Tavşanc1l, Güler ve Ayan, 2014, Worthington \& Whittaker, 2006)) olduğu görülmekte fakat ilgili alanda sunulan bildirilerin incelendiği araştırmaların olmadığ 1 görülmektedir. Bir alanda sunulan bildiriler; ilgili alanın eğilimine, güncel çalışmalarına ve mevcut problemlere çözüm önerileri üretmeye yönelik olduğundan dolayı, sunulan bildirilen bir arada incelenmesi önem arz etmektedir. Bu bağlamda, Eğitimde ve Psikolojide Ölçme ve Değerlendirme Derneği tarafından düzenli olarak iki yılda bir gerçekleştirilen Eğitimde ve Psikolojide Ölçme ve Değerlendirme Kongre'lerinde sunulan bildiri çalışmalarının doküman analizi yöntemi ile incelenmesi önemli görülmüştür. $\mathrm{Bu}$ nedenle ölçme ve değerlendirme alanındaki bu boşluğu kapatmak amacıyla bu alanda yapılan bildiriler nitel araştırma desenlerinden durum çalışması ile desenlenmiş ve mevcut veri seti doküman analizi ile incelenmiştir.

\section{Araștırmanın Amacı}

$\mathrm{Bu}$ araştırmanın genel amacı Türkiye'de Eğitimde ve Psikolojide Ölçme ve Değerlendirme Kongrelerinde sunulan bildirilerin eğilimlerinin nasıl olduğunun belirlenmesidir. Bu kapsamda 2008, 2010, 2012 ve 2014 yıllarında Eğitimde ve Psikolojide Ölçme ve Değerlendirme Kongrelerinde sunulmuş olan bildirilerin konu temaları, anahtar kelimeleri, yazarların kurumları ve unvanları, araştırma türü, araştırma modeli/deseni, örneklem büyüklüğü, kullanılan veri türü ve veri toplama aracı incelenmiş̧tir. Bu araştırma kapsamında aşağıdaki sorulara yanıt aranmıştır:

1. Eğitimde ve Psikolojide Ölçme ve Değerlendirme Kongrelerinde sunulan bildirilerin kongrelere göre konu temalarının eğilimi nasıldır?

2. Eğitimde ve Psikolojide Ölçme ve Değerlendirme Kongrelerinde sunulan bildirilerin kongrelere göre yöntem bölümü nasıldır?"
a) araştırma türünün dağılımı nasıldır?
b) araştırma modeli/deseninin dağılımı nasıldır?
c) örneklem büyüklüğü nedir?
d) kullanılan veri türü nedir?
e) kullanılan veri toplama araçları nelerdir? 
3. Eğitimde ve Psikolojide Ölçme ve Değerlendirme Kongrelerinde sunulan çalışmalarda hangi anahtar kelimeler kullanılmıştır?

4. Eğitimde ve Psikolojide Ölçme ve Değerlendirme Kongrelerinde bildiri sunan kişilerin unvanları nedir?

5. Eğitimde ve Psikolojide Ölçme ve Değerlendirme Kongrelerinde bildiri sunan kişilerin kurumlarına göre dağılımı nasıldır?

\section{YÖNTEM}

\section{Araştırmanın Modeli}

Bu araştırma, Eğitimde ve Psikolojide Ölçme ve Değerlendirme Kongresinde yapılan çalışmaların eğilimlerinin nasıl olduğunun betimlenmesi ve var olan durumun yorumlanması amaçlandığ için, nitel bir araştırma olup, nitel araştırma türlerinden durum çalışması ile desenlenmiştir. Veri toplama yöntemi olarak doküman analizi kullanılmıştır.

\section{Evren}

Araştırmanın evrenini 2008, 2010, 2012 ve 2014 yıllarında gerçekleştirilen Eğitimde ve Psikolojide Ölçme ve Değerlendirme Kongrelerinde sunulan bildiriler oluşturmaktadır. İlk olarak 2008 yılında yapılan I. Ulusal Eğitimde ve Psikolojide Ölçme ve Değerlendirme Kongresi Ankara Üniversitesi'nde, 2010 yılında yapılan II. Ulusal Eğitimde ve Psikolojide Ölçme ve Değerlendirme Kongresi Mersin Üniversitesi'nde, 2012 yılında yapılan III. Ulusal Eğitimde ve Psikolojide Ölçme ve Değerlendirme Kongresi Bolu Abant İzzet Baysal Üniversitesi'nde ve 2014 yılında yapılan IV. Ulusal Eğitimde ve Psikolojide Ölçme ve Değerlendirme Kongresi ise Hacettepe Üniversitesi ev sahipliğinde gerçekleştirilmiştir. Araştırma doğrudan evren üzerinden yapılmış olup her hangi bir örnekleme yöntemi kullanılmamıştır. Araştırma kapsamında incelenen bildirilere ilişkin betimsel istatistikler Tablo 1'de verilmiştir.

Tablo 1. Kongrelere göre Bildirilerin Betimsel İstatistikleri

\begin{tabular}{llcc}
\hline Yıl & Kongreler & Frekans & Yüzde (\%) \\
\hline 2008 & I. Ulusal Eğitimde ve Psikolojide Ölçme ve Değerlendirme Kongresi & 60 & 24.2 \\
2010 & II. Ulusal Eğitimde ve Psikolojide Ölçme ve Değerlendirme Kongresi & 42 & 16.9 \\
2012 & III. Ulusal Eğitimde ve Psikolojide Ölçme ve Değerlendirme Kongresi & 52 & 21.0 \\
2014 & IV. Ulusal Eğitimde ve Psikolojide Ölçme ve Değerlendirme Kongresi & 94 & 37.9 \\
\hline \multicolumn{2}{l}{ Toplam } & 248 & 100 \\
\hline
\end{tabular}

Tablo 1 incelendiğinde çalışmada toplam 248 bildiri incelenmiştir, bu bildirilerin $(n=60) \% 24.2$ 'si 2008 yılında gerçekleştirilen I. Ulusal Eğitimde ve Psikolojide Ölçme ve Değerlendirme Kongresinde, (n=42) \%16.9'u 2010 yılında gerçekleştirilen II. Ulusal Eğitimde ve Psikolojide Ölçme ve Değerlendirme Kongresinde, (n=52) \%21.0'1 2012 yılında gerçekleştirilen III. Ulusal Eğitimde ve Psikolojide Ölçme ve Değerlendirme Kongresinde ve (n=94) \%37.9'u ise 2014 yılında gerçekleştirilen IV. Ulusal Eğitimde ve Psikolojide Ölçme ve Değerlendirme Kongresinde sunulmuştur.

\section{Verilerin Toplanmast ve Analizi}

Araştırmada Eğitimde ve psikolojide ölçme ve değerlendirme kongrelerinde sunulan bildirilere ulaşabilmek için, ilgili kongreleri düzenleyen akademisyenler ile iletişime geçilmiş bunun sonucunda 2008, 2010 ve 2012 yıllarındaki kongrelerde sunulan bildirilerin tam metinlerine 2014 yılındaki kongrede ise özet metinlerine ulaşılmıştır. Ayrıca ilgili kongreleri düzenleyen Eğitimde ve 
Psikolojide Ölçme ve Değerlendirme Derneği (EPODDER) yönetimi ile iletişime geçilmiş ve gerekli izinler alınmıştır. $\mathrm{Bu}$ kapsamda toplam olarak 248 bildiriye ulaşılmış ve araştırmacılar tarafından incelenmeye alınmıştır.

Veri toplama aracı olarak, araştırmacılar tarafindan geliştirilen Ek 1'deki "Bildiri İnceleme Formu" kullanılmıştır. Bu form üç kısımdan oluşmaktadır. Birinci kısımda bildirinin künyesi, ikinci kısımda bildirinin teması, üçüncü kısımda bildirinin yöntemi kısımlarından oluşmaktadır. Veri toplama aracının hazırlanmasında ilk olarak ilgili alan yazında daha önce başka araştırmacılar tarafindan hazırlanılan formlar incelenmiştir. Daha sonra araştırmacılarla iletişime geçilip dönüt alınmış ve en son olarak ölçme ve değerlendirme uzmanı olan 7 kişinin görüşü sonucunda form son halini almıştır.

Araştırma kapsamında doküman analiziyle incelenen bildirilerden elde edilen verinin analizinde betimsel istatistikler ve kelime frekans sorgusu kullanılmıştır. Kelime frekans sorgusu analizi bir metinde geçen kelimelerin frekanslarını hesaplamakta ve frekans ağırlıklarına göre görsel sonuçlar oluşturmaktadır. Kelime/değişken sayısının çok fazla olduğu durumlarda kelime/değişken frekanslarının tablo halinde verilmesi zor olmaktadır, böyle durumlarda kelime frekans sorgusu analizinde frekansa göre ağırlıklandırılmış görsel şekillerin verilmesi bulguların yorumlanmasını kolaylaştırmaktadır.

Bildirilerin konu teması incelenirken EPOD kongrelerinin sitesinde yer alan ve kongreye bildiri gönderilebilecek konuları ifade eden konu temalarından yararlanılmıştır. Bu konu temalarına ek olarak araştırmacılar tarafından eksikliği hissedilen bazı konu temaları eklenmiştir. Ayrıca bu temalar dışında kalan konular "diğer" konu teması altında ifade edilmiştir.

\section{İnandırıcılık (Güvenirlik) ve Aktarılabilirlik (Geçerlik) Çalışması}

Araştırma kapsamında kullanılan EPOD bildiri sınıflama formu için kodlayıcılar arası puanlama güvenirliğini belirlemek amacıyla rasgele seçilen 6 bildiri her araştırmacı tarafindan veri toplama arac1 doğrultusunda oluşturulan forma göre ayrı ayrı bağımsız olarak kodlanmış ve kodlayıcılar arasındaki farklılıkların olup olmadığını belirlemek için uzlaşma katsayısı hesaplanmıştır.

Güvenirlik = Uzlaşma sayısı / (Uzlaşma sayısı + Uzlaşmama sayısı)

Güvenirlik $=0.933$ olarak bulunmuştur.

Elde edilen sonuç ile kodlayıcılar arası tutarlılık anlamındaki güvenirliğinin sağlandığını görülmüştür.

\section{BULGULAR}

Bu bölümde, araştırma sürecinde toplanan verilerden elde edilen bulgu ve yorumlara yer verilmiştir. Her bir alt problem sirasıyla ele alınmıştır.

\section{Birinci Araştırma Sorusuna Ait Bulgular}

Araştırmanın birinci alt amacı olarak "Eğitimde ve Psikolojide Ölçme ve Değerlendirme Kongrelerinde sunulan bildirilerin kongrelere göre konu temalarının eğilimi nasıldır?" sorusuna yanıt aranmıştır. Şekil 1'de 2008 EPOD kongresinde sunulan bildirilerin konu temalarına göre yüzde olarak dağılımı yer almaktadır. 


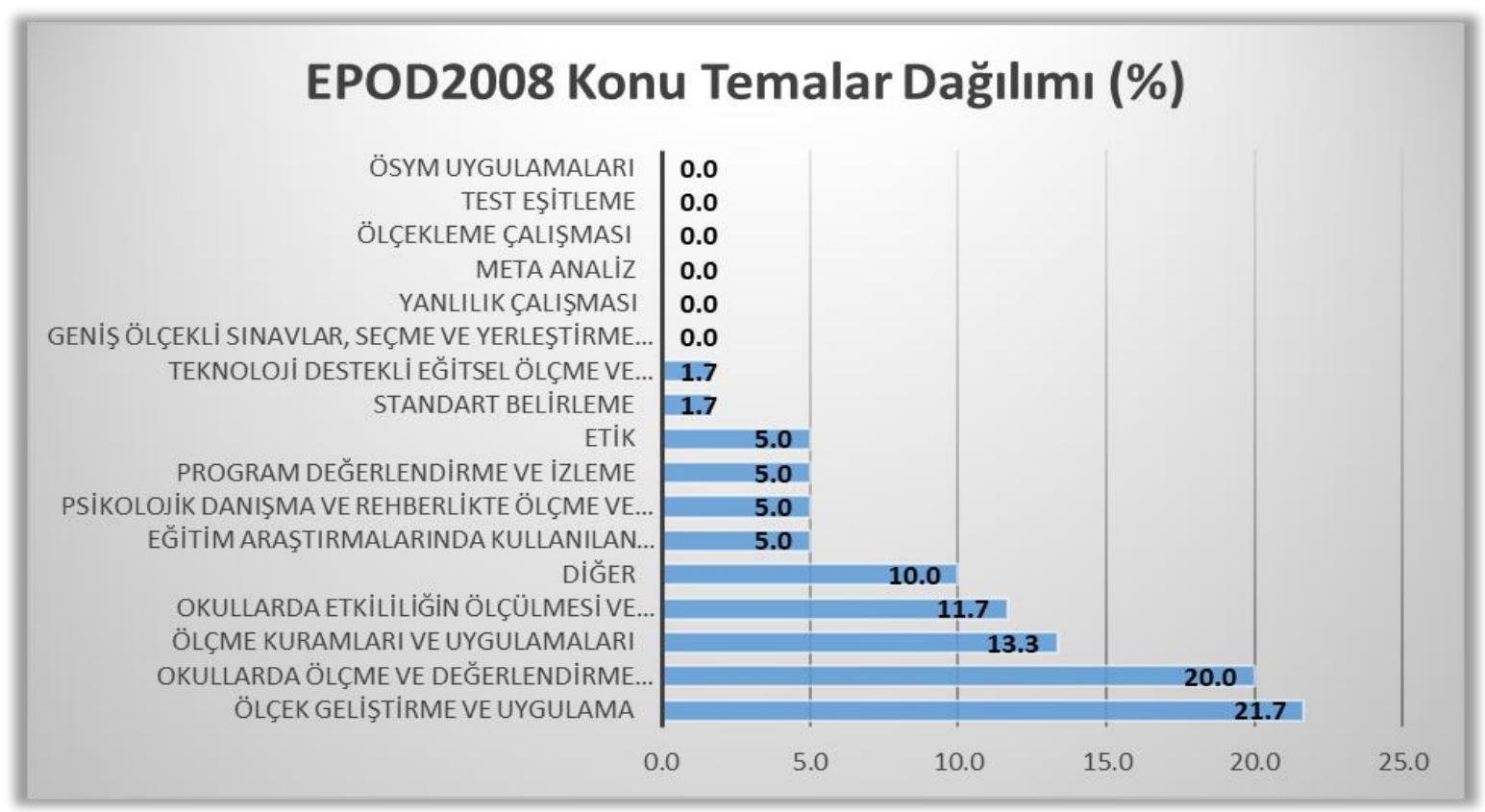

Şekil 1. EPOD 2008 Kongresine göre Konu Temalarının Yüzde Dağılımı

Şekil 1 incelendiğinde EPOD 2008 kongresinde en fazla \%21.7 (n=13) "Ölçek geliştirme ve uyarlama" konu temasında bildiri sunulmuştur. Ölçek geliştirme ve uyarlama temasında sunulan bildirilerin çoğunluğu ise ölçek geliştirme $(\mathrm{n}=10)$ çalışmasıdır. EPOD 2008 kongresinde "ÖSYM Uygulamaları", "Test eşitleme", "Ölçekleme çalışması", "Meta Analiz", "Yanlılık Çalışması" ve "Geniş ölçekli sınavlar, seçme ve yerleştirme sınavları, yüksek riskli sınavlar" temalarında hiçbir bildiri sunulmamıştır. Ayrıca en az \%1.7 $(\mathrm{n}=1)$ "Teknoloji Destekli Eğitsel Ölçme ve Değerlendirme" ve "Standart Belirleme" temalarında bildiri sunulmuştur.

Şekil 2‘de 2010 EPOD kongresinde sunulan bildirilerin konu temalarına göre yüzde olarak dağılımı yer almaktadır.

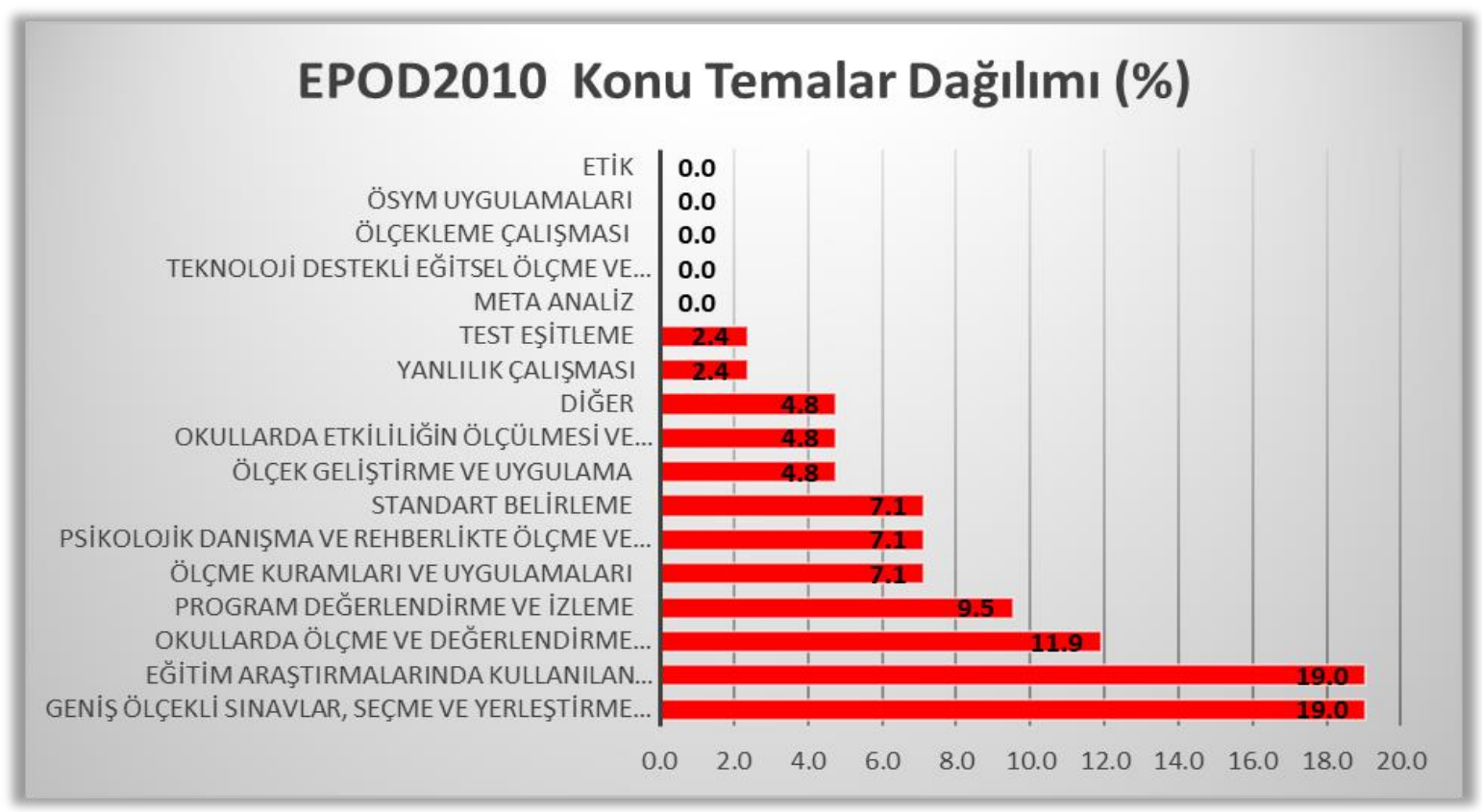




\section{Şekil 2. EPOD 2010 Kongresine göre Konu Temalarının Yüzde Dağılımı}

Şekil 2 incelendiğinde EPOD 2010 kongresinde en fazla "Eğitim araştırmalarında kullanılan istatistiksel yönelimler" ve "Geniş ölçekli sınavlar, seçme ve yerleştirme sınavları, yüksek riskli sınavlar" konu temasında bildiri (\%19 (n=8)'u) sunulmuştur. Eğitim araştırmalarında kullanılan istatistiksel yönelimler temasında yapılan çalışmaların yapısal eşitlik modelle ve regresyon analizi konularında, geniş ölçekli sınavlar, seçme ve yerleştirme sınavları, yüksek riskli sınavlar temasında yapılan çalışmaların ise Uluslararası Matematik ve Fen Eğilimleri Araştırması ve Seviye Belirleme sınavlarıyla ilgili konulara da yoğunlaştığı belirlenmiştir. EPOD 2010 kongresinde "Etik", "ÖSYM Uygulamaları", "Ölçekleme çalışması" ve "Meta Analiz" konu temalarında hiçbir bildiri sunulmamıştır. Ayrıca en az \%2.4 (n=1) "Test Eşitleme" ve "Yanlılık Çalışması" temalarında bildiri sunulmuştur.

Şekil 3'te 2012 EPOD kongresinde sunulan bildirilerin konu temalarına göre yüzde olarak dağılımı yer almaktadır.

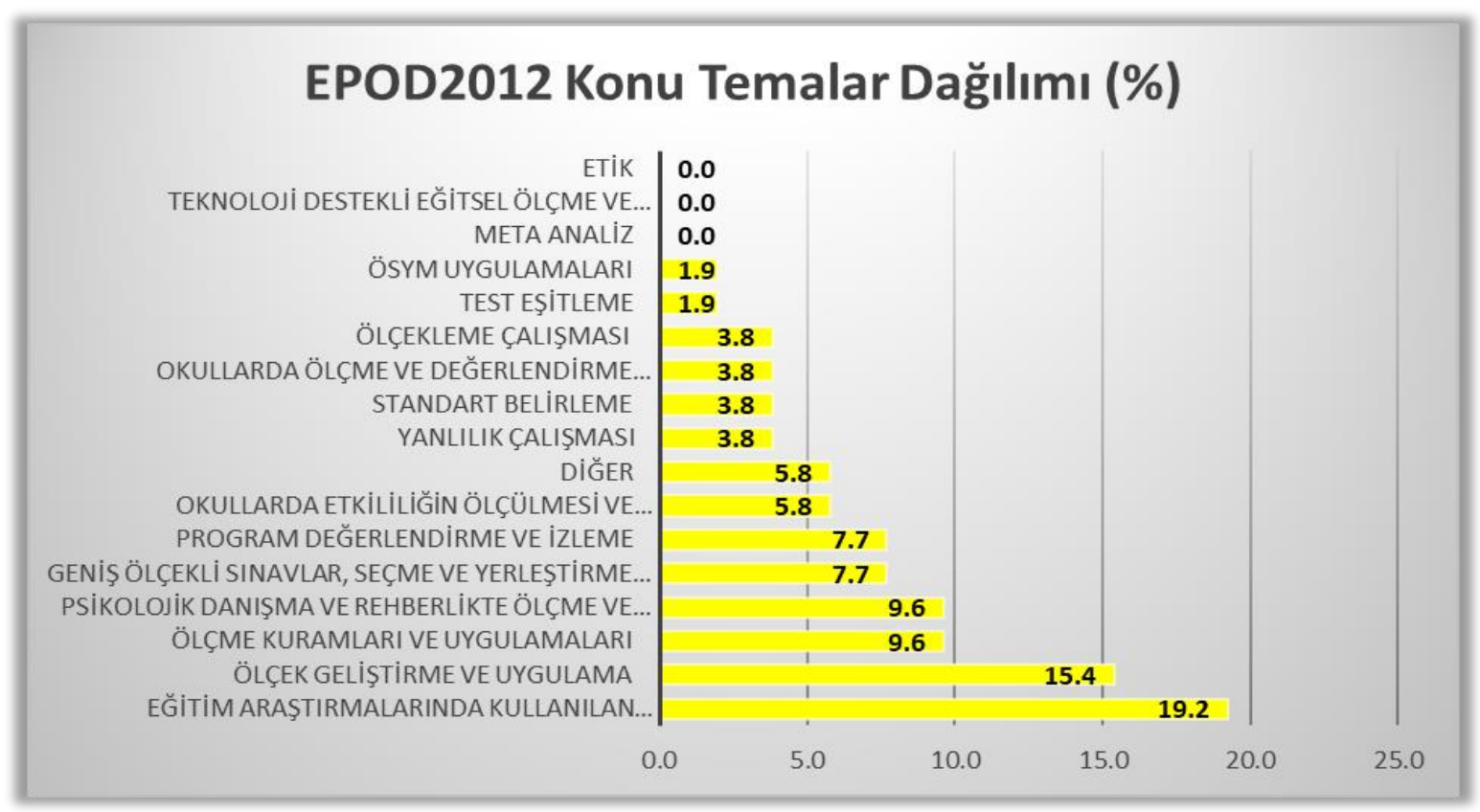

Şekil 3. EPOD 2012 Kongresine göre Konu Temalarının Yüzde Dağılımı

Şekil 3. incelendiğinde EPOD 2012 kongresinde en fazla \%19.2 (n=10)'u "Eğitim araştırmalarında kullanılan istatistiksel yönelimler" konu temasında bildiri sunulmuştur. Eğitim araştırmalarında kullanılan istatistiksel yönelimler temasında yapılan çalışmaların yapısal eşitlik modelleri ile ilgili konularda yoğunlaştığı belirlenmiştir. EPOD 2012 kongresinde "Etik", "Teknoloji Destekli Eğitsel Ölçme ve Değerlendirme" ve "Meta Analiz" temalarında hiçbir bildiri sunulmamıştır. Ayrıca en az \%1.9 (n=1) "Test Eşitleme" ve "ÖSYM uygulamaları" temalarında bildiri sunulmuştur.

Şekil 4'te 2014 EPOD kongresinde sunulan bildirilerin konu temalarına göre yüzde olarak dağılımı yer almaktadır. 


\section{EPOD2014 Konu Temalar Dağılımı (\%)}

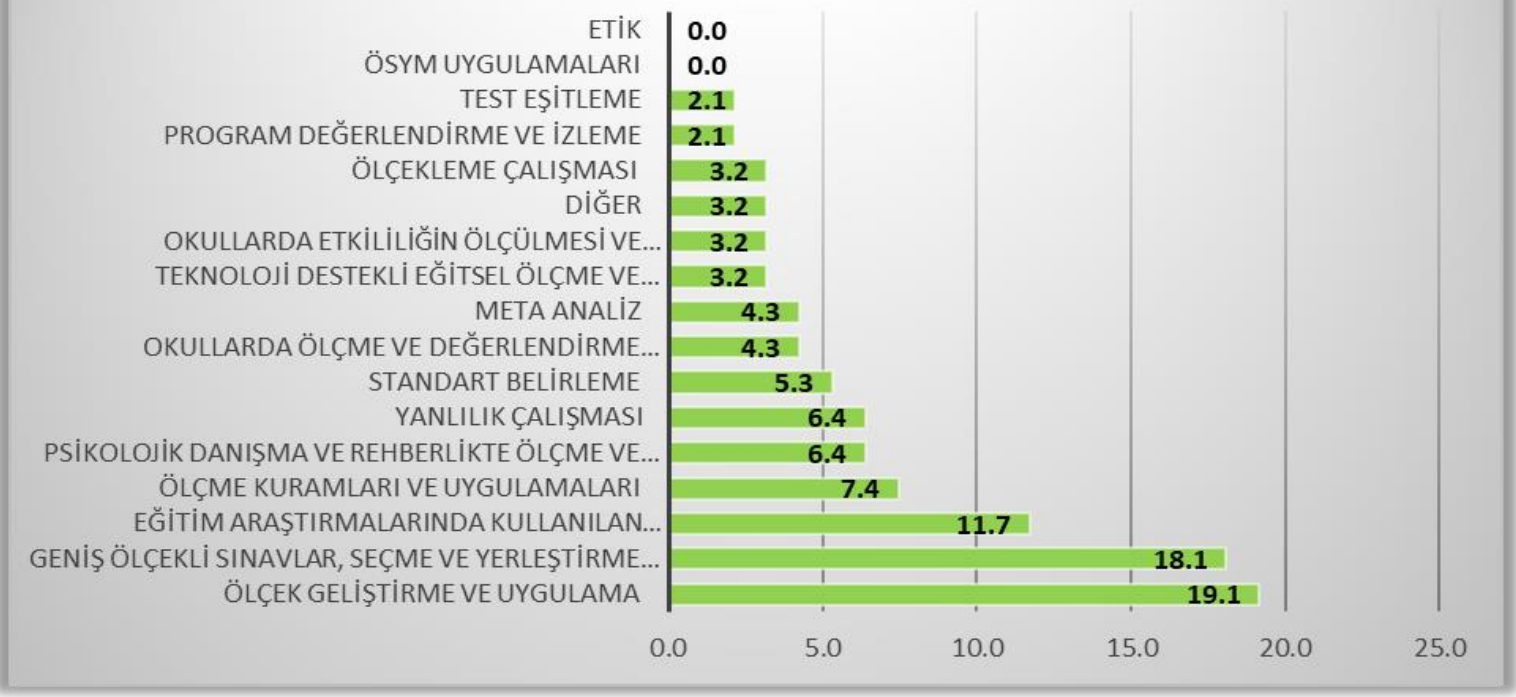

Şekil 4. EPOD 2014 Kongresine göre Konu Temalarının Yüzde Dağılımı

Şekil 4 incelendiğinde EPOD 2014 kongresinde en fazla \%19.1 (n=18)'u "Ölçek Geliștirme ve Uyarlama" konu temasında bildiri sunulmuştur. Ölçek geliştirme ve uyarlama temasında sunulan bildirilerin çoğunluğu ise ölçek geliştirme ( $\mathrm{n}=11)$ çalışmasıdır. EPOD 2014 kongresinde "Etik" ve "ÖSYM Uygulamaları" temalarında hiçbir bildiri sunulmamıştır. Ayrıca en az \%2.1 (n=2) "Test Eşitleme" ve "Program Değerlendirme ve İzleme" temalarında bildiri sunulmuştur.

İlk olarak 2008 yılında yapılan ve daha sonra her iki yılda bir düzenlenen EPOD kongreleri bağımsız olarak ayrı ayrı konu temalarına göre incelendikten sonra 2008, 2010, 2012 ve 2014 yıllarında düzenlenen toplam dört kongre konu temasına göre bir arada incelenmiştir. Tablo 2'de tüm (2008, 2010, 2012 ve 2014) EPOD kongresinde sunulan bildirilerin konu temalarına göre dağıllımı yer almaktadir.

Tablo 2. EPOD Kongrelerine göre Konu Temalarının Dağılımı

\begin{tabular}{|c|c|c|c|c|c|c|}
\hline \multirow{2}{*}{ TEMALAR } & \multicolumn{4}{|c|}{ Kongreler } & \multicolumn{2}{|c|}{ Toplam } \\
\hline & 2008 & 2010 & 2012 & 2014 & $\mathbf{N}$ & $\%$ \\
\hline Ölçek Geliştirme ve Uyarlama & 13 & 2 & 8 & 18 & 41 & 16.5 \\
\hline Eğitim araştırmalarında kullanılan istatistiksel yönelimler & 3 & 8 & 10 & 11 & 32 & 12.9 \\
\hline Geniş ölçekli sınavlar, seçme ve yerleștirme sınavları, yüksek riskli sınavlar & 0 & 8 & 4 & 17 & 29 & 11.7 \\
\hline Ölçme kuramları ve uygulamaları & 8 & 3 & 5 & 7 & 23 & 9.3 \\
\hline Okullarda ölçme ve değerlendirme uygulamaları & 12 & 5 & 2 & 4 & 23 & 9.3 \\
\hline Psikolojik danıșma ve rehberlikte ölçme ve değerlendirme & 3 & 3 & 5 & 6 & 17 & 6.9 \\
\hline Okullarda etkililiğin ölçülmesi ve değerlendirilmesi & 7 & 2 & 3 & 3 & 15 & 6.0 \\
\hline Diğer & 6 & 2 & 3 & 3 & 14 & 5.6 \\
\hline Program değerlendirme ve izleme & 3 & 4 & 4 & 2 & 13 & 5.2 \\
\hline Standart Belirleme & 1 & 3 & 2 & 5 & 11 & 4.4 \\
\hline Yanlılık Çalışması & 0 & 1 & 2 & 6 & 9 & 3.6 \\
\hline Ölçekleme Çalışması & 0 & 0 & 2 & 3 & 5 & 2.0 \\
\hline Meta Analiz & 0 & 0 & 0 & 4 & 4 & 1.6 \\
\hline Teknoloji Destekli Eğitsel Ölçme ve Değerlendirme & 1 & 0 & 0 & 3 & 4 & 1.6 \\
\hline Test Eşitleme & 0 & 1 & 1 & 2 & 4 & 1.6 \\
\hline Etik & 3 & 0 & 0 & 0 & 3 & 1.2 \\
\hline ÖSYM Uygulamaları & 0 & 0 & 1 & 0 & 1 & 0.4 \\
\hline Toplam & 60 & 42 & 52 & 94 & 248 & 100 \\
\hline
\end{tabular}


Tablo 2 incelendiğinde EPOD kongrelerinde sunulan bildirilerin genel olarak "Ölçek Geliştirme ve Uyarlama", "Eğitim araştırmalarında kullanılan istatistiksel yönelimler" ve "Geniş ölçekli sınavlar, seçme ve yerleştirme sınavları, yüksek riskli sınavlar" konu temalarında yoğunlaştığı görülmektedir. Ayrıca "ÖSYM Uygulamaları" ve "Etik" konu temalarında çok fazla çalışma yapılmadığı görülmektedir. Ayrıca belirlenen 16 konu temasından her hangi birisine girmeyen çalışmalar Tablo 2'de "diğer" konu teması olarak belirtilmiş olup, yapılan çalışmaların \%5.6 (n=14)'sı "diğer" konu temasinda yer almaktadır.

Şekil 5'te tüm EPOD kongresinde sunulan bildirilerin konu temalarına göre yüzde olarak dağılımı yer almaktadır.

\section{Kongrelere Göre Konu Temaları Dağılımı (\%)}

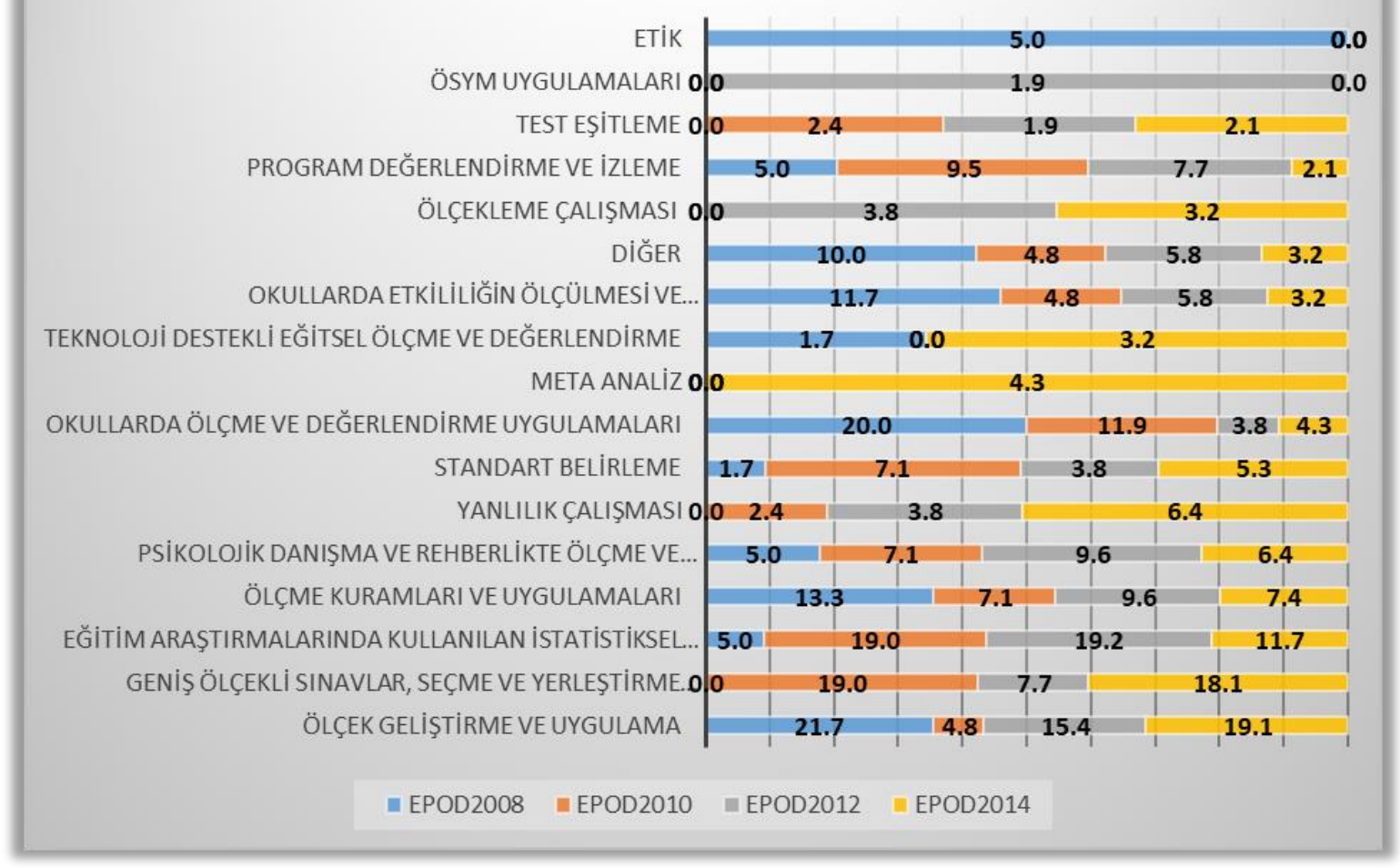

Şekil 5. EPOD Kongresine göre Konu Temalarının Yüzde Dağılımı

Şekil 5 incelendiğinde, "Etik" konu temasıyla ilgili bildiri çalışmasının sadece 2008 EPOD kongresinde, "ÖSYM Uygulamaları" konu temasıyla ilgili bildiri çalışmasının sadece 2010 EPOD kongresinde, "Meta Analiz" konu temasıyla ilgili bildiri çalışmasının sadece 2014 EPOD kongresinde, "Teknoloji Destekli Eğitsel Ölçme ve Değerlendirme" konu temasıyla ilgili bildiri çalışmasının sadece 2008 EPOD ve 2014 EPOD kongrelerinde sunulduğu görülmektedir. "Test eşitleme" konu temasında 2010 EPOD kongresinden itibaren, "Ölçekleme Çalışması" konu temasında 2012 EPOD kongresinden itibaren bildiriler sunulmaya başlanmıştır. "Program Değerlendirme ve İzleme" konu teması ile ilgili her kongrede bildiri sunulmuş olup, 2010 EPOD kongresinden itibaren sunulan bildiri yüzdelerinde bir düşüş olduğu belirlenmiştir. "Okullarda etkililiğin ölçülmesi ve değerlendirilmesi” konu temasıyla ilgili yapılan bildiri çalışmalarında 2010 yılı hariç, yıllara göre yüzde olarak azalma olmuştur. Benzer şekilde "Okullarda Ölçme ve Değerlendirme Uygulamaları" konu temasıyla ilgili yapılan bildiri çalışmalarında ise 2014 yılı hariç yıllara göre yüzde olarak azalma meydana gelmiştir. EPOD kongrelerinde "Yanlılık Çalışması" konu temasıyla ilgili bildiri çalışmalarının yıllara göre sürekli bir artış olduğu tespit edilmiştir. 


\section{İkinci Araştırma Sorusuna Ait Bulgular}

Araştırmanın ikinci alt amacı olarak "Eğitimde ve Psikolojide Ölçme ve Değerlendirme Kongrelerinde sunulan bildirilerin kongrelere göre yöntem bölümü nasıldır?" sorusuna yanıt aranmıştır. Bu kapsamda ilk olarak Tablo 3'te Eğitimde ve Psikolojide Ölçme ve Değerlendirme Kongrelerinde sunulan bildirilerin kongrelere göre araştırma türünün dağılımının nasıl olduğu yer almaktadır.

Tablo 3. EPOD Kongrelerine göre Bildirinin Türü

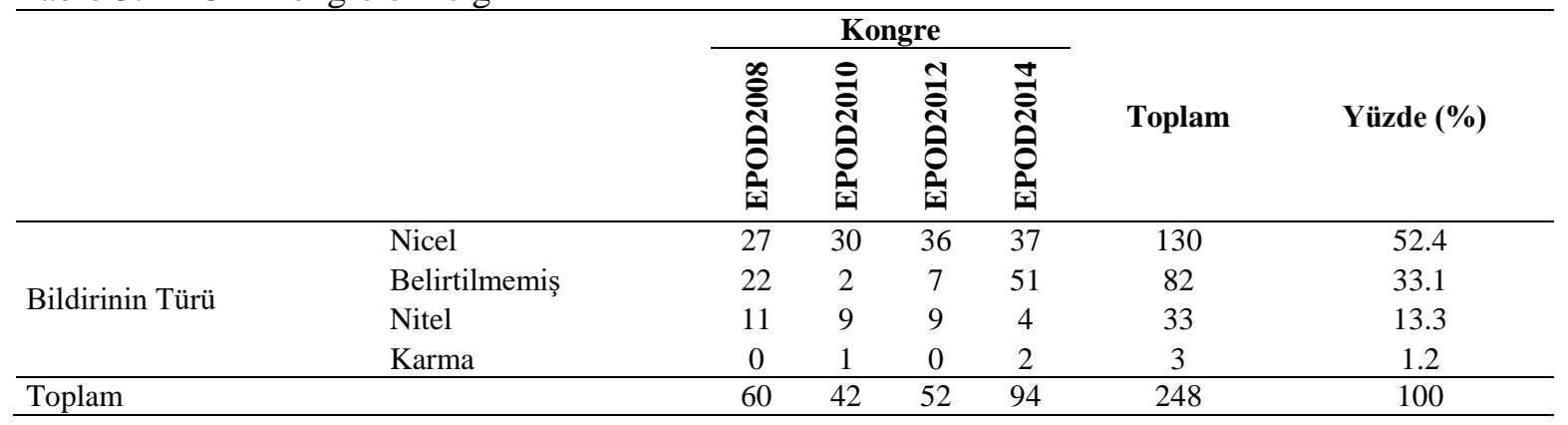

Tablo 3 incelendiğinde kongrelerde sunulan bildirilerden $(n=130) \% 52.4$ nicel araştırma türünde, $(n=82) \% 33.1$ 'i araştırma türü belirtilmeyen, $(n=33) \% 13.3$ 'ü nitel araştırma türünde ve $(n=3)$ $\% 1.2$ 'sinin ise karma araştırma türünde olduğu görülmektedir. Kongrelerde sunulan bildirilerde en çok tercih edilen araştırma türünün nicel, en az tercih edilen ise karma araştırma türünde olduğu belirlenmiştir. Ayrıca EPOD 2014'te bildiri türü belirtmeyenlerin sayısının diğer kongrelere göre daha yüksek olduğu görülmektedir. Bunun sebebinin daha önceden de belirtildiği gibi 2014 EPOD kongrelerinin sadece kısa özetlerine ulaşılabilmiş ve araştırma verileri kısa özetten elde edilmesinden kaynaklanabileceği düşünülmektedir.

Tablo 4'te Eğitimde ve Psikolojide Ölçme ve Değerlendirme Kongrelerinde sunulan bildirilerin kongrelere göre araştırma modeli/deseni dağılımı nasıl olduğu yer almaktadır.

Tablo 4. EPOD Kongrelerine göre Araştırma Modeli/Deseni 


\begin{tabular}{|c|c|c|c|c|c|c|c|}
\hline & & \multicolumn{4}{|c|}{ Kongre } & \multirow[b]{2}{*}{ Toplam } & \multirow[b]{2}{*}{ Yüzde $(\%)$} \\
\hline & & 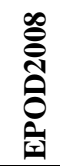 & $\begin{array}{l}\text { 옳 } \\
\text { Оิ } \\
\text { ○ิ }\end{array}$ & 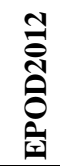 & 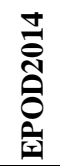 & & \\
\hline \multirow{14}{*}{ Araştırma Modeli/Desen } & Belirtilmemiş & 34 & 14 & 23 & 67 & 138 & 55.6 \\
\hline & Tarama & 12 & 8 & 11 & 11 & 42 & 17.0 \\
\hline & Betimsel araştırma & 8 & 7 & 8 & 2 & 25 & 10.1 \\
\hline & Korelasyonel & 0 & 2 & 4 & 6 & 12 & 4.8 \\
\hline & Doküman analizi & 1 & 3 & 1 & 2 & 7 & 2.8 \\
\hline & Temel Araştırma & 0 & 3 & 2 & 1 & 6 & 2.4 \\
\hline & Meta-Analiz & 0 & 0 & 0 & 4 & 4 & 1.6 \\
\hline & Deneysel & 1 & 2 & 1 & 0 & 4 & 1.6 \\
\hline & Durum çalışması & 1 & 1 & 0 & 1 & 3 & 1.2 \\
\hline & Olgu bilim & 2 & 0 & 1 & 0 & 3 & 1.2 \\
\hline & Kuramsal araştırma & 0 & 1 & 0 & 0 & 1 & 0.4 \\
\hline & Eylem araştırması & 0 & 1 & 0 & 0 & 1 & 0.4 \\
\hline & Örnek Olay & 1 & 0 & 0 & 0 & 1 & 0.4 \\
\hline & Kuram oluşturma & 0 & 0 & 1 & 0 & 1 & 0.4 \\
\hline Toplam & & 60 & 42 & 52 & 94 & 248 & 100 \\
\hline
\end{tabular}

Tablo 4 incelendiğinde kongrelerde sunulan bildirilerin $(n=138) \% 55,6$ 'sının araştırma modeli/deseni belirtilmemiştir. Kongrelerde en çok tercih edilen araştırma modelleri/desenleri ise $(n=42) \% 17.0^{\prime} i$ "Tarama", (n=25) \%10.1'i "Betimsel araştırma" olduğu belirlenirken, en az tercih edilen araştırma türü ise $(\mathrm{n}=1) \% 0,4$ ile "Kuram oluşturma", "Örnek olay", "Eylem Araştırması" ve "Kuramsal araştırma" olduğu görülmektedir.

Tablo 5' te Eğitimde ve Psikolojide Ölçme ve Değerlendirme Kongrelerinde sunulan bildirilerin kongrelere göre örneklem büyüklükleri yer almaktadır.

Tablo 5. EPOD Kongrelerine göre Örneklem Büyüklüğü

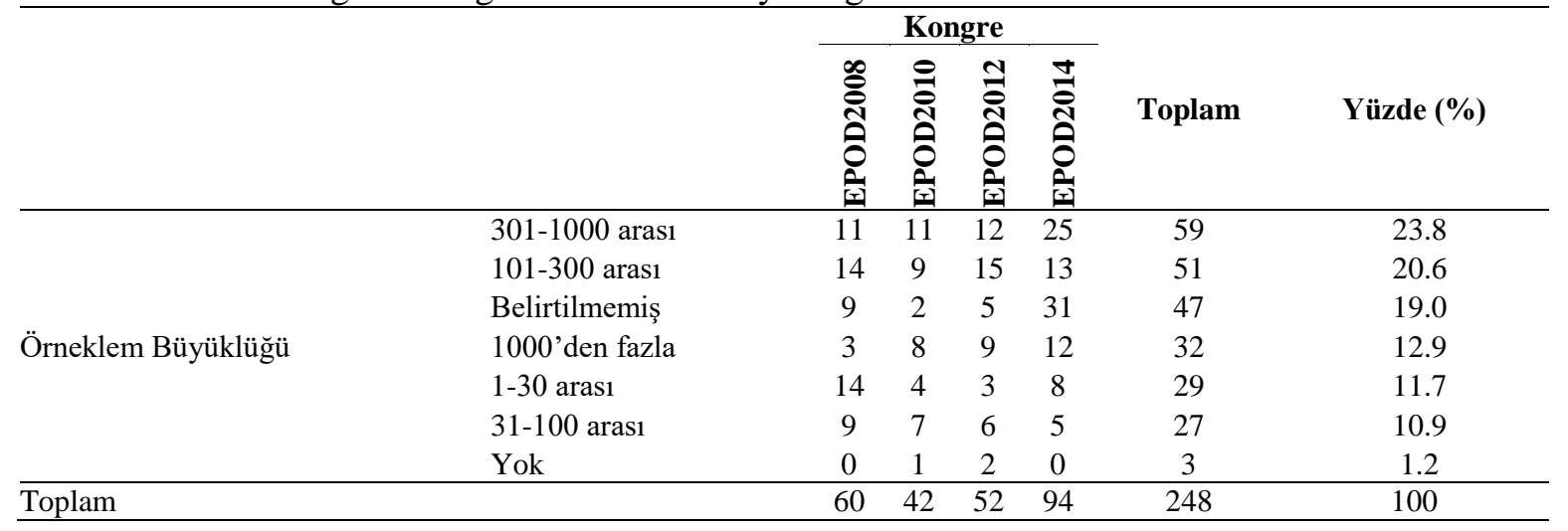

Tablo 5 incelendiğinde kongrelerde sunulan bildirilerde en çok tercih edilen örneklem büyüklükleri $(n=59)$ \%23.8 ile "301-1000 arası" ve $(n=51) \% 20.6$ ile "101-300 arası" olduğu görülmektedir. Ayrıca sunulan bildirilerden (n=47) \%19.0'1nın ise örneklem büyüklükleri belirtilmemiştir. Özellikle EPOD 2014'te örneklem büyüklü belirtmeyenlerin sayısı diğer kongrelere göre daha yüksek olduğu görülmektedir. Bunun sebebinin daha önceden de belirtildiği gibi 2014 EPOD kongrelerinin sadece kısa özetlerine ulaşılabilmiş ve araştırma verileri kısa özetten elde edilmesinden kaynaklanabileceği düşünülmektedir. Kongrelerde sunulan bildirilerde en az tercih edilen örneklem büyüklügü ise $(\mathrm{n}=27) \% 10.9$ ile "31-100 arası" olduğu görülmektedir. Sunulan bildirilerin $(\mathrm{n}=3) \% 1.2$ 'sinin ise örneklem büyüklüğü olmayan ve tabloda "yok" ile belirtilen kuramsal çalışmalardır. 
Koyuncu, M.S., Şata, M., Karakaya, İ. / Eğitimde Ölçme ve Değerlendirme Kongrelerinde Sunulan Bildirilerin Doküman Analizi Yöntemi ile İncelenmesi

Tablo 6'da Eğitimde ve Psikolojide Ölçme ve Değerlendirme Kongrelerinde sunulan bildirilerin kongrelere göre kullanılan veri türü yer almaktadır.

Tablo 6. EPOD Kongrelerine göre Kullanılan Veri Türü

\begin{tabular}{|c|c|c|c|c|c|c|c|}
\hline & & & Kon & gre & & & \\
\hline & & 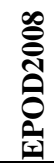 & 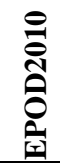 & 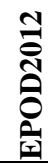 & 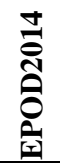 & Toplam & Yüzde (\%) \\
\hline & Uygulama Verisi & 40 & 23 & 36 & 43 & 142 & 57.3 \\
\hline & Hazır Veri & 7 & 10 & 13 & 19 & 49 & 19.8 \\
\hline Kullanılan Veri Türï & Belirtilmemiş & 10 & 1 & 1 & 23 & 35 & 14.1 \\
\hline Nuntantall vent turu & Simülasyon Verisi & 1 & 2 & 1 & 9 & 13 & 5.2 \\
\hline & Yok & 1 & 6 & 1 & 0 & 8 & 3.2 \\
\hline & Hazır ve Uygulama verisi & 1 & 0 & 0 & 0 & 1 & 0.4 \\
\hline Toplam & & 60 & 42 & 52 & 94 & 248 & 100 \\
\hline
\end{tabular}

Tablo 6 incelendiğinde kongrelerde sunulan bildirilerde en çok kullanılan veri türü $(n=142) \% 57.3$ ile "uygulama verisi" ve $(\mathrm{n}=49) \% 19.8$ ile "Hazır veri" olduğu görülmektedir. Ayrıca sunulan bildirilerden (n=35) \%14.1'ının ise kullanılan veri türü belirtilmemiştir. Kongrelerde sunulan bildirilerde en az kullanılan veri türü ise $(n=1) \% 0.4$ ile "Hazır ve Uygulama verisi" nin bir arada kullanıldığı çalışma olduğu görülmektedir. Sunulan bildirilerin $(n=8) \% 3.2$ 'sinin ise veri türü yoktur.

Tablo 7'de Eğitimde ve Psikolojide Ölçme ve Değerlendirme Kongrelerinde sunulan bildirilerin kongrelere göre veri toplama araçları yer almaktadır.

Tablo 7. EPOD Kongrelerine göre Veri Toplama Aracı

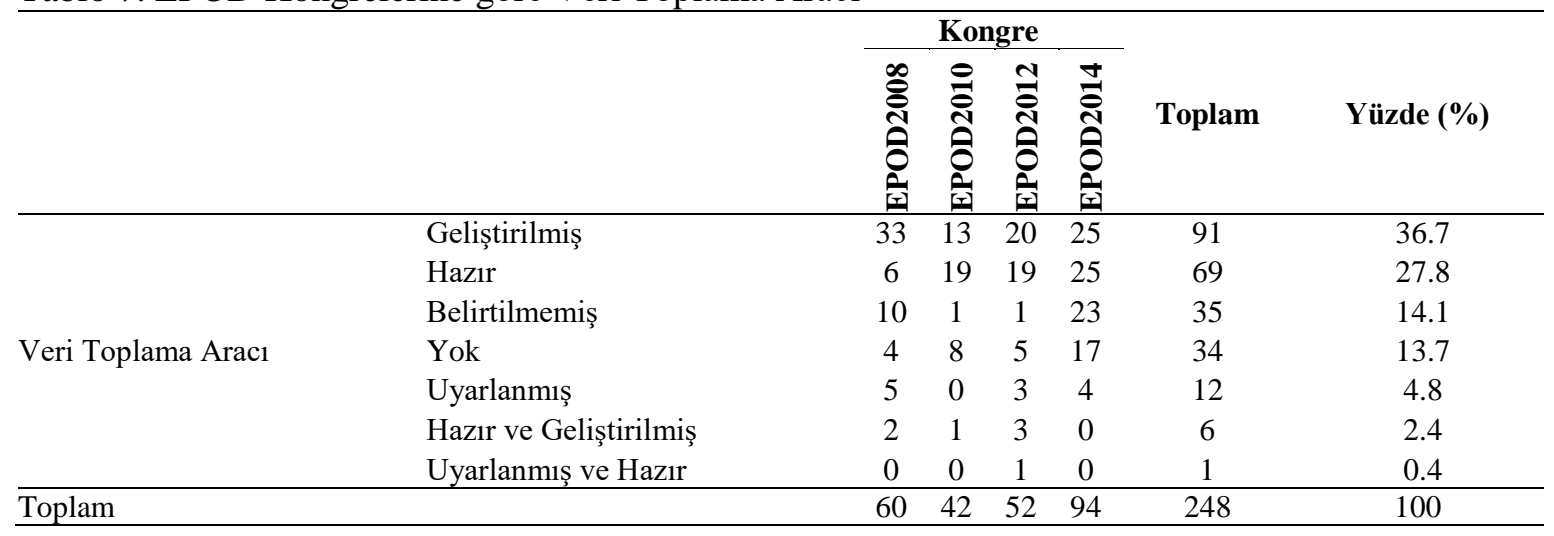

Tablo 7 incelendiğinde kongrelerde sunulan bildirilerde en çok kullanılan veri toplama aracı $(\mathrm{n}=91)$ \%36.7 ile "Geliştirilmiş" ve (n=69) \%27.8 ile "Hazır" veri toplama araçları olduğu görülmektedir. Ayrıca sunulan bildirilerden $(\mathrm{n}=35) \% 14.1$ 'ının ise kullanılan veri toplama aracı belirtilmemiştir. Bazı çalışmalarda ise birden çok veri toplama aracının bir arada kullanıldığı belirlenmiştir. Kongrelerde sunulan bildirilerde en az kullanılan veri toplama arac1 ise $(n=1) \% 0.4$ ile "Hazır ve Uyarlanmış" veri toplama aracının bir arada kullanıldı̆̆g çalışma olduğu görülmektedir. Sunulan bildirilerin $(\mathrm{n}=34) \% 13.7$ 'sinin ise veri toplama arac1 yoktur.

\section{Dördüncü Araşttrma Sorusuna Ait Bulgular}


Araştırmanın dördüncü alt amacı olarak "Eğitimde ve Psikolojide Ölçme ve Değerlendirme Kongrelerinde sunulan çalışmalarda hangi anahtar kelimeler kullanılmıştır?" sorusuna yanıt aranmıştır. Tablo 8'de EPOD kongrelerinde kullanılan anahtar kelimelerin frekans sorgusu yer almaktadır. Sunulan bildirilerdeki anahtar kelime sayısı çok fazla olduğundan, anahtar kelime frekansları tablo halinde verilmeyip kelime frekans sorgusu kullanılarak frekansa göre ağırlandırılmış görsellerle sunulmuştur

Tablo 8. EPOD Kongreleri “Anahtar Kelime” Kelime Frekans Sorgusu
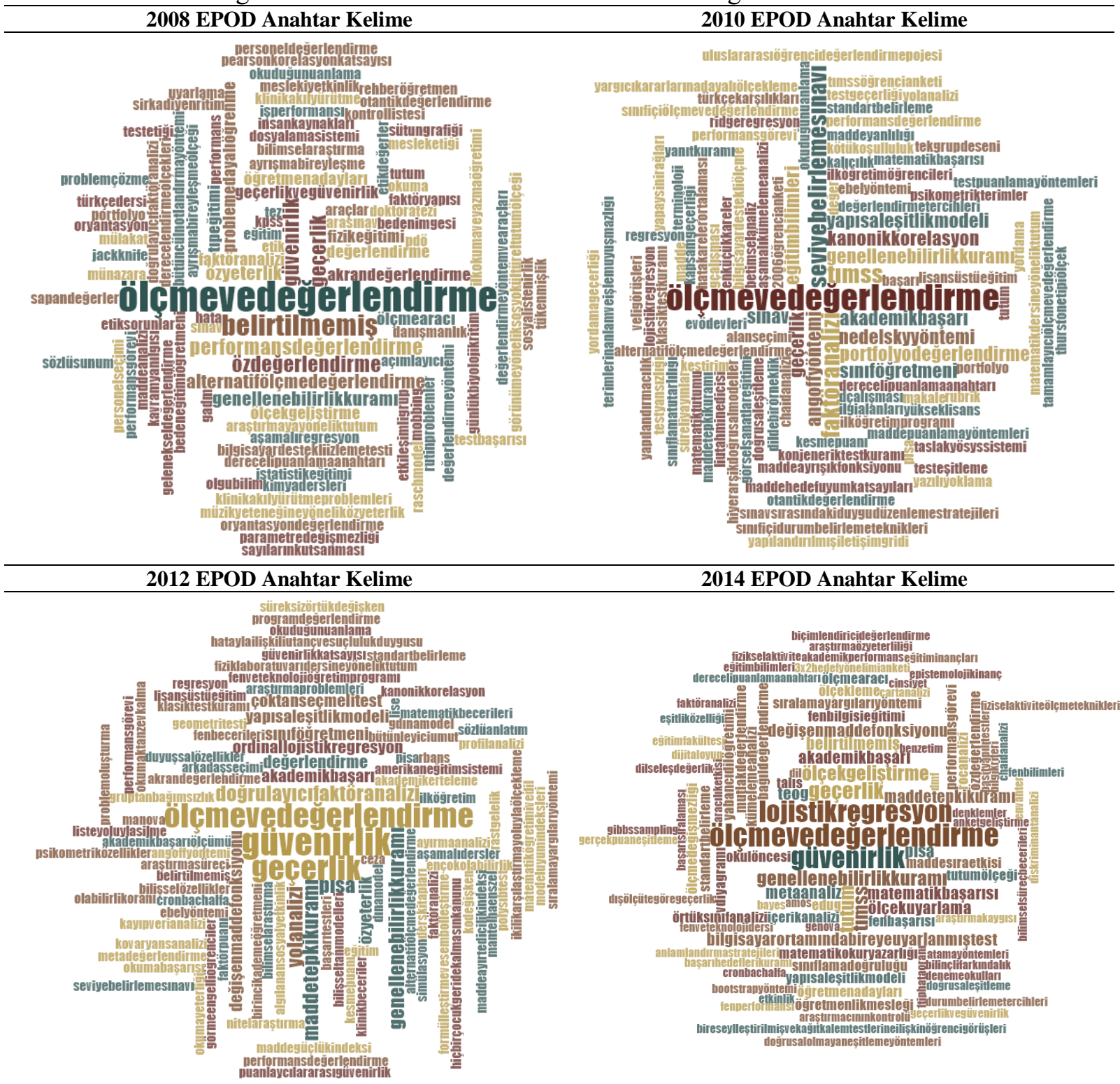

Tablo 8 incelendiğinde EPOD 2008'de sunulan bildirilerde en çok kullanımı tercih edilen anahtar kelime "ölçme ve değerlendirme" olduğu bulunmuştur. Anahtar kelime belirtmeyenlerin yani "belirtilmemiş" "in ise ne yüksek ikinci frekansa sahip olduğu bulunmuştur. Daha sonra ise "geçerlik" ve "güvenirlik" anahtar kelimelerinin ön plana çıktığı belirlenmiştir. Kullanımı en çok tercih edilen anahtar kelimeler EPOD 2010'da sirasıyla "ölçme ve değerlendirme", "faktör analizi", ve "seviye belirleme sınavı" olduğu; EPOD 2012' de sırasıly "güvenirlik", "geçerlik" ve "ölçme ve değerlendirme"; EPOD 2014'te ise sirasıyla "ölçme ve değerlendirme", "güvenirlik" ve "lojistik regresyon" olduğu belirlenmiştir. Genel olarak bakıldığında ise EPOD 2012 dışındaki diğer 
Koyuncu, M.S., Şata, M., Karakaya, İ. / Eğitimde Ölçme ve Değerlendirme Kongrelerinde Sunulan Bildirilerin Doküman Analizi Yöntemi ile İncelenmesi

kongrelerde kullanımı en çok tercih edilen anahtar kelimenin "ölçme ve değerlendirme" olduğu, sadece EPOD 2012'de “güvenirlik" olduğu görülmektedir.

Şekil 6'da ise tüm kongrelerin bir arada ele alınmasıyla elde edilen kelime frekans sorgusu yer almaktadır. Ayrıca Şekil 6'da kelime frekans sorgusu sonucunda elde edilen şekillerin büyüklükleri, kelimenin frekans ağırlı̆̆ ile doğru orantılıdır.

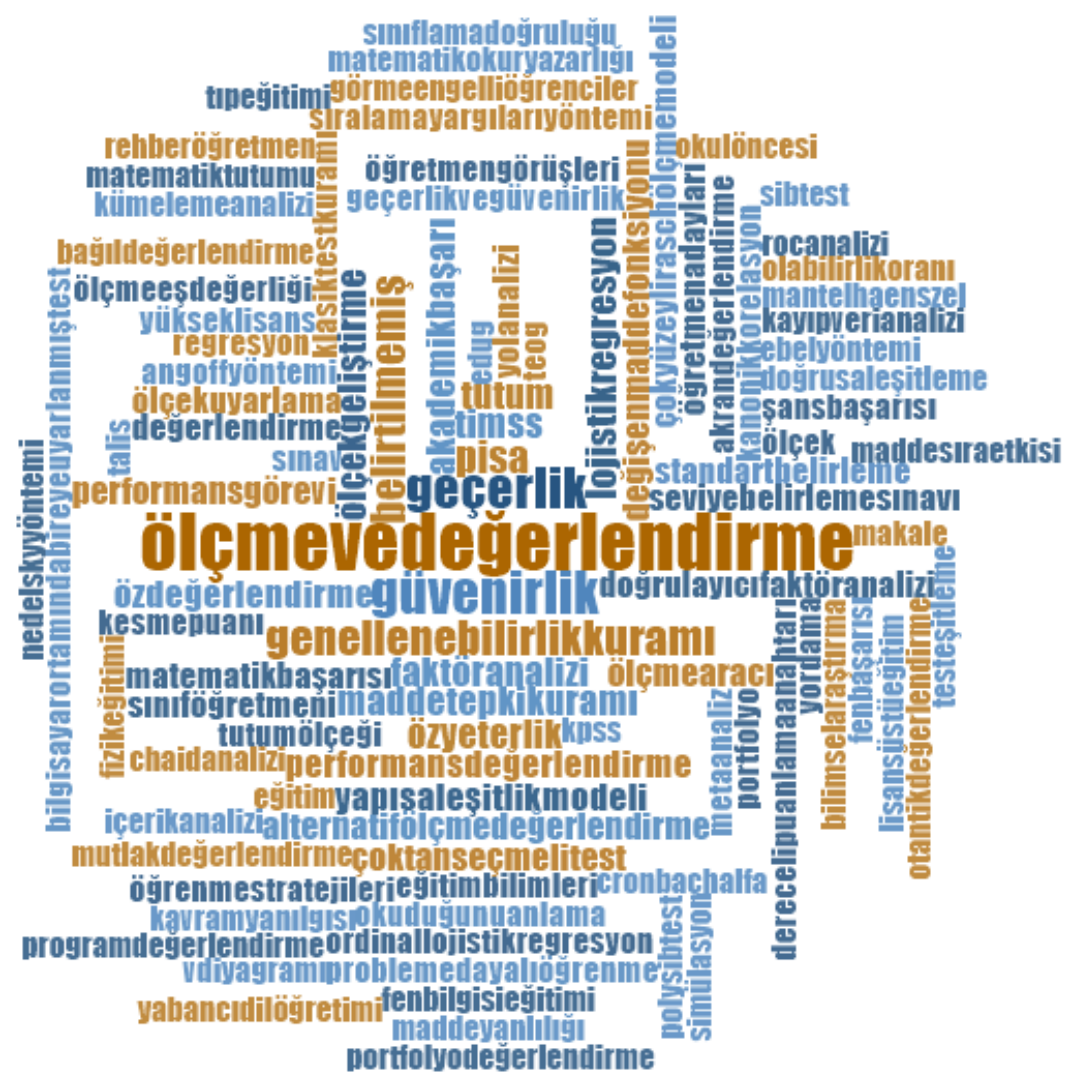

Şekil 6. Genel EPOD “Anahtar Kelime” Kelime Frekans Sorgusu

Şekil 6 incelendiğinde yapılan tüm kongrelerde kullanımı en çok tercih edilen anahtar kelimelerin sırasıyla \%3.74 (n=31) "ölçme ve değerlendirme", \%2.17 ( $\mathrm{n}=18)$ "güvenirlik" ve \%2.05 (n=17) "geçerlik" anahtar kelimeleri olduğu belirlenmiştir.

\section{Beşinci Araştırma Sorusuna Ait Bulgular}

Araştırmanın beşinci alt amacı olarak "Eğitimde ve Psikolojide Ölçme ve Değerlendirme Kongrelerinde bildiri sunan kişilerin unvanlara göre dağılımı nasıldır?" sorusuna yanıt aranmıştır. Yapılan tüm EPOD kongrelerinde bildiri sunan kişilerin unvanlara göre dağılımı Tablo 9'da yer almaktadır. 
Tablo 9. EPOD Kongreleri "Unvan" Kelime Frekans Sorgusu 2008 EPOD Unvan
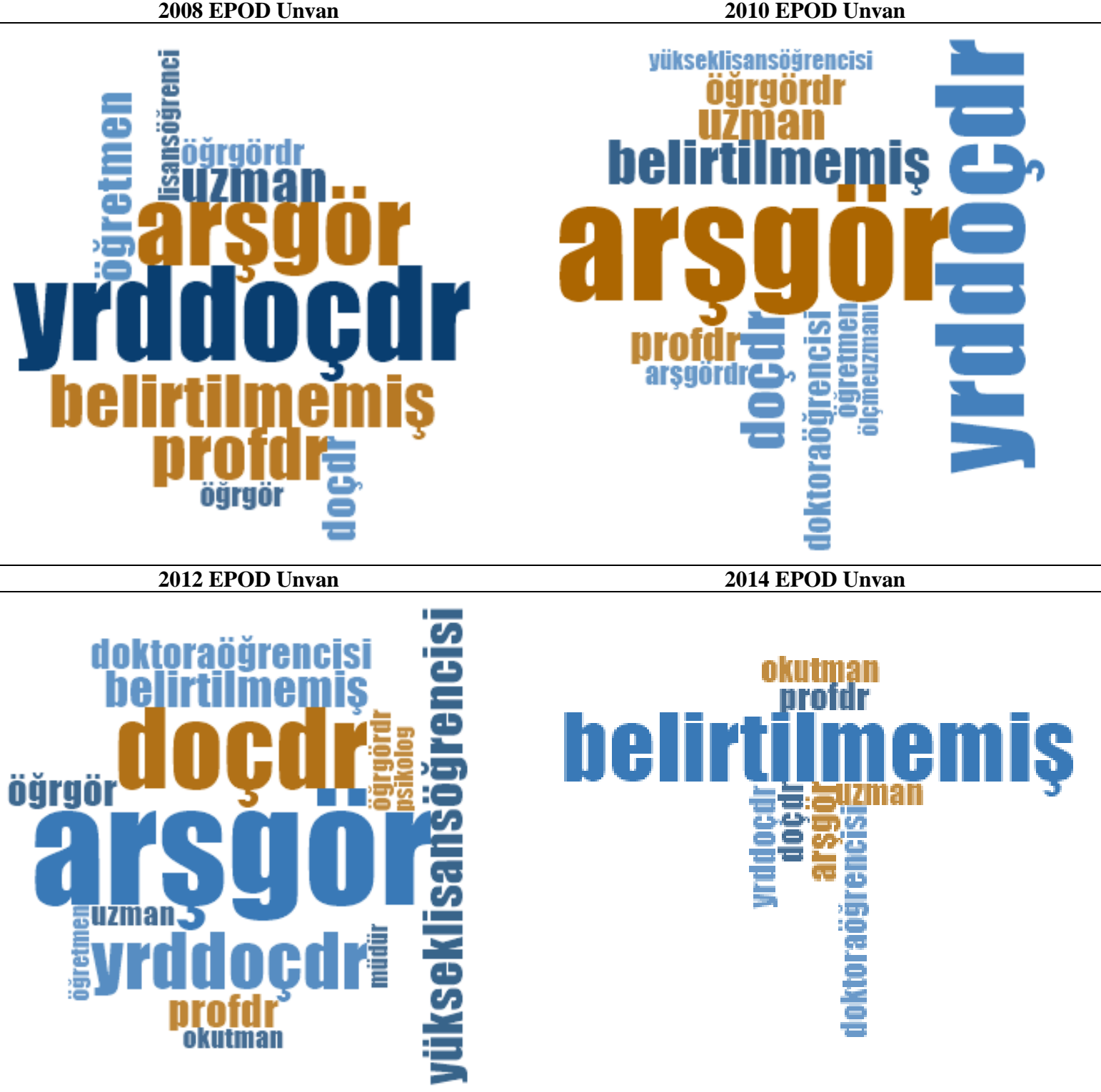

Tablo 9 incelendiğinde bildiri sunan kişilerin EPOD 2008'de en fazla "Yrd.Doç.Dr." ve "Arş. Gör." unvanlarına sahip olduğu, EPOD 2010'da "Arş. Gör." ve "Yrd. Doç. Dr." unvanlarına sahip olduğu, EPOD 2012'de "Arş. Gör." ve "Doç. Dr." unvanlarına sahip olduğu ve EPOD 2014'de ise unvanlarını belirtmeyenleri ifade eden "belirtmemiș" lerin ağırlıkta olduğu daha sonra ise sırasıyla "Arş. Gör." ve "Prof. Dr." unvanlarına sahip olduğu görülmektedir. Tablodaki elde edilen şekillerin büyüklükleri frekans ağırlıklarıyla orantılı olduğundan dolayı, özellikle EPOD 2014'te "belirtilmemiş" frekansının diğer unvanlara göre çok yüksek olduğu görülmektedir. Bunun sebebinin daha önceden de belirtildiği gibi 2014 EPOD kongrelerinin sadece kısa özetlerine ulaşılabilmiş ve araştırma verileri kısa özetten elde edilmesinden kaynaklanabileceği düşünülmektedir.

Tablo 10' da tüm kongrelerin bir arada ele alınmasıyla elde edilen bildiri sunan kişilerin unvanlarına ait frekans tablosu yer almaktadır.

Tablo 10. Tüm EPOD Kongrelerinde Bildiri Sunan Kişilerin Unvanlara göre Frekans Dağılımı 
Koyuncu, M.S., Şata, M., Karakaya, İ. / Eğitimde Ölçme ve Değerlendirme Kongrelerinde Sunulan Bildirilerin Doküman Analizi Yöntemi ile İncelenmesi

\begin{tabular}{lcc}
\hline Unvan & Frekans & Yüzde (\%) \\
\hline Belirtilmemiş & 186 & 36.40 \\
Arş. Gör. & 94 & 18.40 \\
Yrd. Doç. Dr. & 65 & 12.72 \\
Doç. Dr. & 42 & 8.22 \\
Prof. Dr. & 33 & 6.46 \\
Uzman & 21 & 4.11 \\
Dr. & 15 & 2.94 \\
Doktora öğrencisi & 10 & 1.96 \\
Öğretmen & 10 & 1.96 \\
Yüksek lisans öğrencisi & 9 & 1.76 \\
Öğr. Gör. Dr. & 9 & 1.76 \\
Öğr. Gör. & 7 & 1.37 \\
Okutman & 4 & 0.78 \\
Arş. Gör. Dr. & 2 & 0.39 \\
Lisans öğrencisi & 1 & 0.20 \\
Müdür & 1 & 0.20 \\
Psikolog & 1 & 0.20 \\
Ölçme uzmanı & 1 & 0.20 \\
\hline Toplam & 511 & 100 \\
\hline
\end{tabular}

Tablo 10 incelendiğinde yapılan tüm kongreler de unvan belirtmeyenlerin yani "belirtilmemiş" kategorisinin en yüksek frekansa $(n=186)$ sahip olduğu belirlenmiştir. Bunun sebebinin daha önceden de belirtildiği gibi 2014 EPOD kongrelerinin sadece kısa özetlerine ulaşılabilmiş ve araştırma verileri kısa özetten elde edilmesinden kaynaklanabileceği düşünülmektedir. Daha sonra kongrelerde bildiri sunan kişilerin sırasıyla "Arş. Gör.", "Yrd. Doç. Dr.” ve "Doç. Dr.” unvanlarına sahip olduğu bulunmuştur.

\section{Altıncı Araştırma Sorusuna Ait Bulgular}

Araştırmanın altıncı alt amacı olarak "Eğitimde ve Psikolojide Ölçme ve Değerlendirme Kongrelerinde bildiri sunan kişilerin kurumlarına göre dağılımı nasıldır?" sorusuna yanıt aranmıştır. Yapılan tüm EPOD kongrelerinde bildiri sunan kişilerin kurumlarına göre dağılımı Tablo 11'de yer almaktadır. 
Tablo 11. EPOD Kongreleri "Kurum” Kelime Frekans Sorgusu

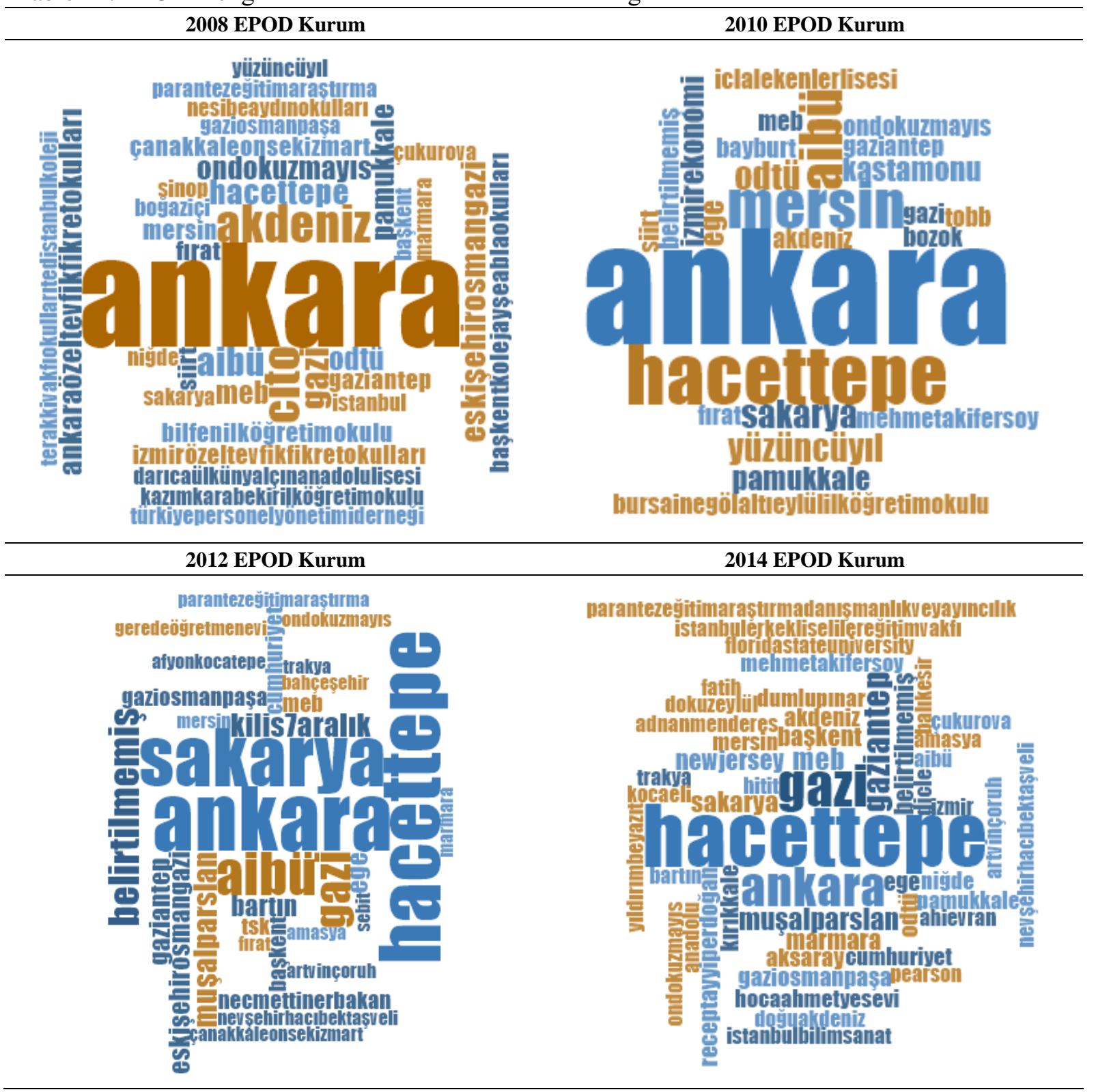

Tablo 11 incelendiğinde bildiri sunan kişilerin EPOD 2008'de sırasıyla en fazla "Ankara", "Akdeniz" üniversitesi ve "Cito" mensubu olduğu, EPOD 2010'da sirasiyla en fazla "Ankara", "Hacettepe" ve "Mersin" üniversitesi mensubu olduğu, EPOD 2012'de sirasiyla en fazla "Ankara", "Hacettepe" ve "Sakarya" üniversitesi mensubu olduğu ve EPOD 2014'de ise sirasiyla en fazla "Hacettepe", "Gazi" ve "Ankara " üniversitesi mensubu olduğu görülmektedir. Ayrıca yapılan tüm EPOD kongrelerinde bildiri sunan kişilerin kurumlarına göre dağılımı ise Şekil 7'de yer almaktadır. 


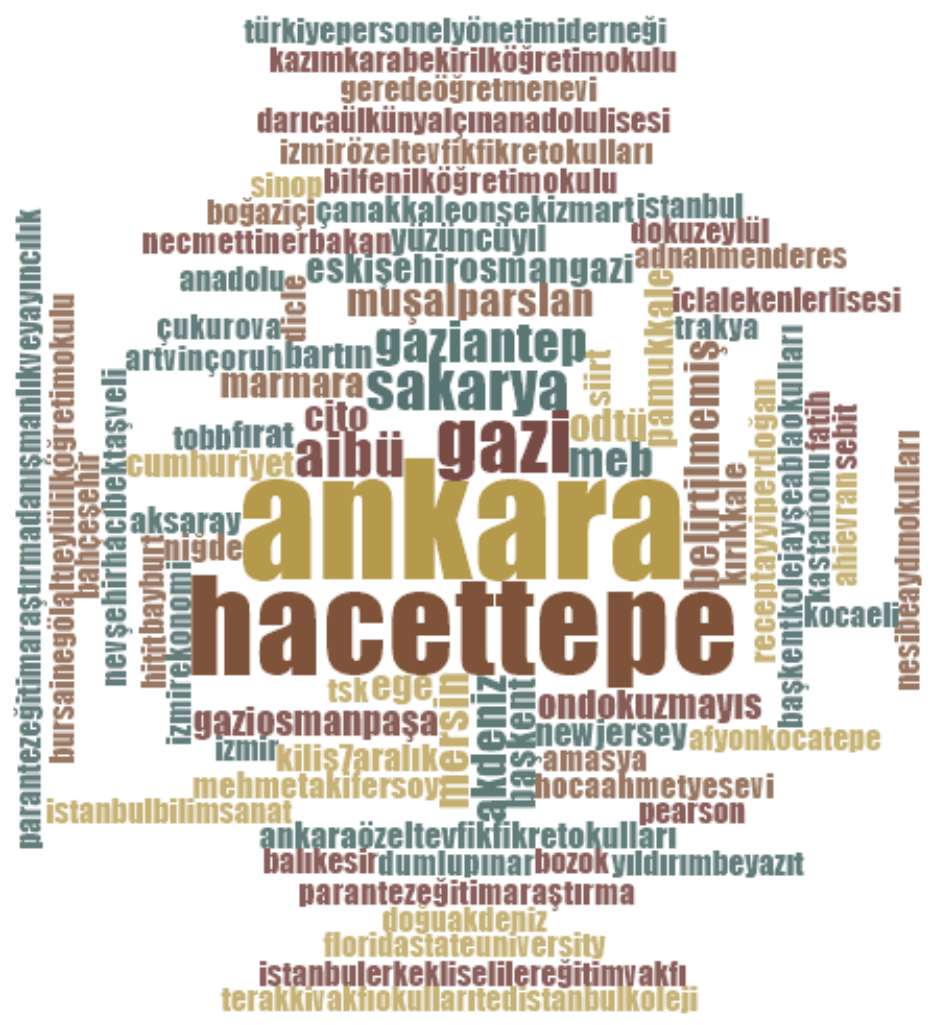

Şekil 7. Tüm EPOD Kongrelerinde Bildiri Sunan Kişilerin Kurum Dağılımı

Şekil 7 incelendiğinde kongrelerde en çok bildiri sunan kişilerin kurumlarının sırasıyla \%18.47 (n=94) Ankara, \%14.93 (n=76) Hacettepe ve \%7.66 (n=39) Gazi üniversitesi olduğu belirlenmiștir. Ankara'daki bu üniversitelerde eğitimde ölçme ve değerlendirme yüksek lisans ve doktora programının olmasının ve eğitimde ölçme ve değerlendirme alanında istihdam edilen akademik personel sayısın diğer üniversitelerden daha fazla olmasının sonucun bu şekilde çıkmasında etkili olduğu düşünülmektedir.

\section{SONUÇLAR ve TARTIŞMA}

Bu araştırmada, 2008-2014 yılları arasında yapılmış dört Eğitimde ve Psikolojide Ölçme ve Değerlendirme Kongresinde sunulan bildiriler çeşitli değişkenlere göre incelenmiştir. Elde edilen bulgular her bir araştırma sorusu doğrultusunda tartışılmıştır.

Bildirilerin konu temalarının dağılımına ilişkin bulgular incelendiğinde, en fazla çalışılan konu başlığının "Ölçek geliştirme ve uygulama" olduğu en az çalışılan konu başlığının ise "ÖSYM uygulamaları" olduğu görülmüştür. Eğitimde Ölçme ve Değerlendirme alanında yapılan yüksek lisans ve doktora tezlerinin doküman analizi ile incelendiği çalışmalarda da benzer bir eğilimin olduğu görülmektedir (Ayva, Ceyhan ve Doğan, 2015; Şenyurt ve Özkan, 2017). Benzer durum eğitim bilimlerinin diğer alanları/bölümleri için de geçerlidir (Tavşancıl, vd., 2010). Ayrıca eğitim bilimleri dışındaki diğer disiplinlerde yapılan çalışmalar incelendiğinde de veri toplamada en fazla ölçek ve başarı testi kullanıldığı görülmektedir (Küçükoğlu ve Ozan, 2013; Yaşar ve Papatğa 2015). Çalışmanın bulguları ve alanyazın dikkate alındığında bu eğilimin sadece eğitimde ölçme ve değerlendirme alanına özgü olmayıp ulusal bir eğilim olduğu söylenebilir. Bildiri çalışmalarında "ÖSYM uygulamalarının" çok az olmasındaki nedenlerden biri olarak Ölçme, Seçme ve Yerleştirme Merkezi Başkanlığı'nın akademisyenler ile veri paylaşmama politikasından kaynaklandığı düşünülmektedir. Bulgular bölümündeki Tablo 2 incelendiğinde PISA ve TIMSS gibi sınavların en 
çok çalışılan üçüncü konu başlığı olduğu görülmekte bunun temel nedeninin ise bu sinavların kamuoyuna ve bilim insanlarına erişimin açık olmasından kaynaklanmaktadır. Benzer olarak ÖSYM ve MEB böyle bir politikaya sahip olsalar idi araştırmacıların bu kurumların yaptıkları ölçme ve değerlendirme uygulamalarına yönelecekleri düşünülmektedir. Yıllara göre konu dağılımları incelendiğinde ise çoğu konu başlığının yıllar içinde küçük değişimler gösterdiği (örneğin "test eşitleme", "ölçekleme çalışması", diğerleri için şekil 5'e bakınız), bazı konu başlıklarının ise artığı (örneğin "yanlılık çalışması”, "meta analiz" gibi) gözlemlenmiştir.

Bildirilerin yöntem bölümlerinin incelenmesi sonucunda, bildirilerin büyük çoğunluğunun nicel yaklaşımı benimsediği çok azının ise karma (nicel ve nitel yaklaşımın birlikte ele alınması) yaklaşımı benimsediği görülmüştür. Eğitimde Ölçme ve Değerlendirme alanında yapılan lisansüstü tez çalışmalarının ve makale çalışmalarının da benzer bir eğilime sahip oldukları görülmüştür(Erdem, 2011; Acar-Güvendir ve Özer-Özkan, 2015; Ayva, Ceyhan ve Doğan, 2015; Şenyurt ve Özkan, 2017). Bildiri çalışmalarında en fazla nicel yaklaşımlardan tarama modelinin tercih edildiği ve bu durumun alanyazın ile benzerlik gösterdiği bulunmuştur(Tavşancıl, vd., 2010; Erdem, 2011; Ayva, Ceyhan ve Doğan, 2015; Şenyurt ve Özkan, 2017). Ayrıca bildiri çalışmalarının büyük bir çoğunluğunda araştırmanın modelinin belirtilmediği görülmektedir. Bildiri çalışmalarında deneysel desenlerin çok az kullanıldığı benzer eğilimin makale ve lisansüstü tez çalışmalarında da olduğu görülmektedir (Tavşancıl, vd., 2010; Erdem, 2011). Bildiri çalışmalarında kullanılan örneklem büyüklükleri incelendiğinde en fazla tercih edilen örneklem büyüklügünün 101-300 arasında olduğu en az tercih edilen ise 31-100 arasında olduğu görülmektedir. Bu sonuç bildiri çalışmalarının genellikle çalışma grubu üzerinde yapıldığını ve evrene genelleme yapılmadığ gösterir nitelikte olup ölçme ve değerlendirme alanındaki literatür ile uyum içindedir (Tavşancıl, vd., 2010; Ayva, Ceyhan ve Doğan, 2015; Şenyurt ve Özkan, 2017). Kongrelerde sunulan bildiri çalışmalarında kullanılan veri türlerinin dağılımları incelendiğinde en fazla araştırmacıların kendi uygulamaları ile topladığı veri ve ikinci olarak önceden uygulaması yapılmış olan hazır veri olduğu görülmekte ve alanyazın ile uyum göstermektedir. Bildiri çalışmalarında verinin toplanmasında kullanılan ölçme araçlarına ilişkin eğilim incelendiğinde en fazla araştırmacıların kendi geliştirdikleri ölçme araçlarını tercih ettikleri en az ise başka araştırmacıların hazırladıkları ölçme araçlarının kullanıldığı görülmüştür. Elde edilen sonuçlar alanyazın ile ve diğer disiplinlerdeki çalışmalarla uyum göstermektedir (Tavşanc1l, vd., 2010; Küçükoğlu ve Ozan, 2013; Ayva, Ceyhan ve Doğan, 2015; Yaşar ve Papatğa, 2015; Şenyurt ve Özkan, 2017).

Kongrelerde sunulan bildiri çalışmalarında kullanılan anahtar kelime dağılımına ilişkin sonuçlar incelendiğinde, en fazla kullanılan anahtar kelimeler sırasıyla ölçme ve değerlendirme, güvenirlik ve geçerlik olduğu gözlemlenmiştir. Benzer sonuçlar Eğitimde ölçme ve Değerlendirme alanında yapılan ve yüksek lisans ve doktora tezlerinde de mevcuttur (Tavşancıl, vd., 2010).

Eğitimde ve Psikolojide Ölçme ve Değerlendirme Kongresinde bildirileri sunan kişilerin unvan dağılımları incelendiğinde, unvanını belirtmeyenlerin en fazla olduğu daha sonra sırasıyla araştırma görevlisi, yardımcı doçent doktor olduğu en az ise profesör doktor olduğu gözlemlenmiştir. Araştırma görevlerinin daha fazla sayıda bildiri yapmasında, makale yayınından önce bildiri çalışmaları yaparak tecrübe kazanılması, son yıllarda lisansüstü eğitim yönetmenliğinde yapılan değişiklilerde tez savunması için bildiri yapma zorunluluğu, alandaki hocalarla tanışma firsatı gibi etkilerin söz konusu olduğu düşünülmektedir. Benzer olarak yardımcı doçent doktor sayısının da fazla olmasında doçentlik kriterlerinde bildiri yapma şartının bulunması gibi etkilerin olduğu söylenebilir.

Eğitimde ve Psikolojide ölçme ve Değerlendirme alanına özgü yapılan kongrelerde sunulan bildirilerin kurumlara göre dağılımı incelendiğinde, en fazla bildirinin Ankara Üniversitesi’nde çalışan akademisyenler tarafından sunulduğu daha sonra sırasıyla Hacettepe Üniversitesi, Gazi Üniversitesi ve Sakarya Üniversitesi olduğu belirlenmiştir. Eğitimde Ölçme ve Değerlendirme alanında yapılan lisansüstü tezler incelendiğinde benzer bir durumun olduğu bulunmuştur (Tavşanc1l, vd., 2010; Şenyurt ve Özkan, 2017). Bu durumun nedenlerinden biri Ankara Üniversitesi ve Hacettepe Üniversitesinde hem yüksek lisans hem de doktora programının bulunması ve akademik personelin diğer üniversitelere göre daha fazla olmasından kaynaklanmaktadır. 
Doküman analizi ile bildirilerin incelenmesi sonucunda, bildirilerin belli standartlara sahip olmadığ biçimsel olarak birçok eksik yanının bulunduğu (yazar adının olmadığı, anahtar kelimelerinin bulunmadığı, yöntem kısının eksik olduğu) belirlenmiştir. Bu bağlamda bundan sonra yapılacak olan kongrelerde bildirileri için belli standartların olması gerektiği düşünülmektedir. Eğitimde Ölçme ve Değerlendirme alanındaki eğilime bakıldığında Türkiye'deki eğiliminden çok farklı olmadığı ve birçok çalışmanın birbirini tekrar eder nitelikte olduğu belirlenmiştir. Bu bağlamda bundan sonra yapılacak kongrelerde güncel ve farklı konulardaki temaların belirlenmesi ve daha önce yapılmış çalışmaların benzerlerinin kabul edilmemesi gibi sınırlılıkların getirilmesi ilgili alana katkı getireceği düşünülmektedir.

\section{KAYNAKÇA}

Acar-Güvendir, M. ve Özer-Özkan, Y. (2015). Türkiye'deki eğitim alanında yayımlanan bilimsel dergilerde ölçek geliştirme ve uyarlama konulu makalelerin incelenmesi. Elektronik Sosyal Bilimler Dergisi, 14(52), 23-33. Doi: 10.17755/esosder.54872

Ayva, F. G., Ceyhan G. ve Doğan E. G. (2015, Nisan). Türkiye'de eğitimde ölçme ve değerlendirme alanında yapılan doktora tezlerinin doküman analizi yöntemiyle incelenmesi. 24. Ulusal Eğitim Bilimleri Kongresi, Niğde, Türkiye.

Bayram, E. (2011). Öğretmenlerin ölçme ve değerlendirme yeterliklerinin incelenmesi (Yüksek Lisans Tezi, Hacettepe Üniversitesi, Sosyal Bilimler Enstitüsü, Ankara). https://tez.yok.gov.tr/UlusalTezMerkezi/ adresinden edinilmiştir.

Bowen, G. A. (2009). Document analysis as a qualitative research method. Qualitative Research Journal, 9(2), 27-40. Doi: $10.3316 /$ QRJ0902027

Büyüköztürk, Ş., Çakmak, E., Akgün, Ö. E., Karadeniz, Ş. ve Demirel, F. (2012). Bilimsel araştırma yöntemleri (11. Basım). Ankara: Pegem Akademi.

Demirel, Ö ve Şahinel, M. (2006). Türkçe ve sinıf öğretmenleri için türkçe öğretimi. Ankara: Pegem Akademi.

Erdem, D. (2011). Türkiye'de 2005-2006 yılları arasında yayımlanan eğitim bilimleri dergilerindeki makalelerin bazı özellikler açısından incelenmesi: Betimsel bir analiz. Eğitimde ve Psikolojide Ölçme ve Değerlendirme Dergisi, 2(1), 140-147.

Erkuş, A. (2014). Psikolojide ölçme ve ölçek geliştirme-I. Ankara: Pegem Akademi.

Küçükoğlu, A. ve Ozan, C. (2013). Sınıf öğretmenliği alanındaki lisansüstü tezlere yönelik bir içerik analizi. Uluslararast Avrasya Sosyal Bilimler Dergisi, 4(12), 27-47.

Madge, J. (1965). The tools of science an analytical description of social scince techniques. ABD: Anchor.

O'Leary, Z. (2017). The essential guide to doing your research project. London:Sage.

Şenyurt, S. ve Özkan, Y. Ö. (2017). Eğitimde ölçme ve değerlendirme alanında yapılan yüksek lisans tezlerinin tematik ve metodolojik açıdan incelenmesi. İlköğretim Online, 16(2), 628-653.Doi: 10.17051/ilkonline.2017.304724

Tan, Ş. (2012). Öğretimde ölçme ve değerlendirme KPSS el kitabı. Ankara: Pegem Akademi.

Tavşancıl, E., Çokluk, Ö., Çıtak, G. G., Kezer, F., Yıldırım, Ö. Y., Bilican, S., Büyükturan, E. B., Şekercioğlu, G., Yalçın, N., Erdem, E. ve Özmen, D. T. (2010). Eğitim bilimleri enstitülerinde tamamlanmış lisansüstü tezlerin incelenmesi (2000-2008). Ankara Üniversitesi Bilimsel Araştırma Projesi Kesin Raporu, Ankara.

Tavşancıl, E., Güler, G. ve Ayan, C. (2014, Haziran). 2002-2012 Yılları arasında Türkiye'de geliştirilen bazı tutum ölçeği geliştirme çalı̧̧malarının ölçek geliş̧tirme süreci açısından incelenmesi. IV. Ulusal Eğitimde ve Psikolojide Ölçme ve Değerlendirme Kongresi, Ankara, Türkiye.

Yin, R. K. (1994). Case study research: Design and methods. California: Sage Publications Inc.

Yaşar, Ş. ve Papatğa, E. (2015). İlkokul matematik derslerine yönelik yapılan lisansüstü tezlerin incelenmesi. Trakya Üniversitesi Eğitim Fakültesi Dergisi, 5(2), 113-124.

Worthington, R. L., \& Whittaker, T. A. (2006). Scale development research a content analysis and recommendations for best practices. The Counseling Psychologist, 34(6), 806-838. doi: $10.1177 / 0011000006288127$

\section{EXTENDED ABSTRACT}

\section{Introduction}


Document analysis contains analysis of the written materials involving information about a fact or facts which are aimed to investigate. Document analysis is a data collection technique for almost every study. If there is no document, then there is no history (Madge, 1965). Which documents are important and can be used as a data source are closely related to the problem of the study. In the literature, there are studies in which postgraduate and doctorate dissertations together in the measurement and evaluation in education area were examined with document analysis but there are not any studies in which papers were analysed by document analysis. For this reason; to close this gap in the measurement and evaluation area, papers in this field were designed with case study that is one of the qualitative research methods and are examined with available data set document analysis.

General aim of this study is to determine how the trends in papers presented in The Measurement and Evaluation in Education and Psychology (MEEP) Congresses in Turkey are. Within this scope, themes, key words, writers' institutions, type of study, design of study, sample size, data type and data collection tool of papers presented in MEEP Congresses in 2008, 2010, 2012 and 2014 were investigated.

\section{Method}

Since the purpose of this study is to depicture how the trends in papers presented orally in MEEP congresses are and to interpret the existing situation, this study is a case study which is one of the qualitative research designs. Research population is composed of the papers presented in MEEP Congresses in 2008, 2010, 2012 and 2014. The research was directly done with the population and none of the sample methods were used. 248 papers were reviewed in the study. $24,2 \%(n=60)$ of this papers have been presented in The I. National Measurement and Evaluation in Education and Psychology Congress at Ankara University in 2008; 16,9\% ( $\mathrm{n}=42)$ in The II. National Measurement and Evaluation in Education and Psychology Congress at Mersin University in 2010, 21,0\% ( $\mathrm{n}=52$ ) in The III. National Measurement and Evaluation in Education and Psychology Congress at Bolu Abant İzzet Baysal University in 2012 and 37,9\% ( $\mathrm{n}=94)$ in The IV. National Measurement and Evaluation in Education and Psychology Congress at Hacettepe University in 2014. To reach the papers presented in MEEP Congresses, academicians who coordinated these congresses were got in contact with as a result; the whole texts of the papers presented in the congresses in 2008, 2010, 2012 and the abstract texts of the congress in 2014 were obtained. Furthermore, The Administration of the Measurement and Evaluation Congresses in Education and Psychology Association was got contact with and necessary permissions were taken. In this context; 248 papers were totally reached and investigated by the researchers. As a tool of data collection, 'The Paper Examination Form' has been used. This form consists of three parts; the identity of presentation the theme of presentation, and the method of presentation.

\section{Results and Discussion}

It has been observed that the papers presented in MEEP congresses has generally been concentrated in the themes of 'Scale Development and Application', 'Statistical Tendencies Used in Educational Studies' and 'Large scale tests, selection and placement tests, high-stake test'. however, not many studies have been done in the themes of 'ÖSYM Practices' and 'Ethic'. Besides, it has been seen that 'Bias Studies' is the only subject theme that has regularly the rise according to years in studies done. Quantitative research type has generally been preferred in all the congresses. 33,1\% $(n=82)$ of the studies did not state the type of the research. Moreover, qualitative research and mixed research methods were not too much preferred. 55,6\% $(\mathrm{n}=138)$ of the papers did not state the research model/design. Due to the fact that congress in 2014 has only short summaries, it is acceptable for the MEEP 2014 congress. When the ones whose research designs/models were not stated were not taken into account, it has been determined that 'Scanning' with the percent of 10,5\% $(n=26)$, 'Descriptive Research' with the percent of 10,1 $(\mathrm{n}=25)$ were the most preferred research types and 'Grounded Theory', 'Case Study', 'Activity Research', 'Theoretical Research' with the percent of $0,4(n=1)$ were the least preferred research types. In the studies, samples sizes 'between 301 and 1000' and 
'between 101 and 300' were generally utilized. Those studies mostly used 'Enhanced' data collection tool with the percent of $36,7 \%(n=91)$ and 'Prepared' data collection tool with the percent of $27,8 \%(n=69)$ and rarely used 'Prepared and Adapted' with $0,4 \%(n=1)$ were determined. $13,7 \%$ $(n=34)$ of the papers presented do not have a data collection tool. In this sense, the most widely used data type has been stated as "Application Data" with 57,3\% (n=142) and "Ready Made Data" with $19,8 \%(\mathrm{n}=49)$. Moreover, $14,1 \%(\mathrm{n}=35)$ of the presented papers that used data type has not been stated. The most used key words are "measurement and evaluation", "reliability" and "validity", respectively when all categorizes are taken into account in the analysis. In the analyses done according to titles of people presenting a presentation in the congress the category, 'Unspecified', has been stated as having the highest frequency. Later, it was found that researchers presented papers in congresses had the titles of "Res. Asst.", "Asst. Prof." and "Assoc. Prof. Dr." and those researchers presented papers are mostly from the universities "Ankara", "Hacettepe" and "Gazi", respectively on the basis of institution considering MEEP congresses. Besides, it was defined that some papers did not have writer's name, key words in congresses.

It is suggested that studies presented in MEEP Congresses should have a certain standard. 
Ek 1: Bildiri İnceleme Formu

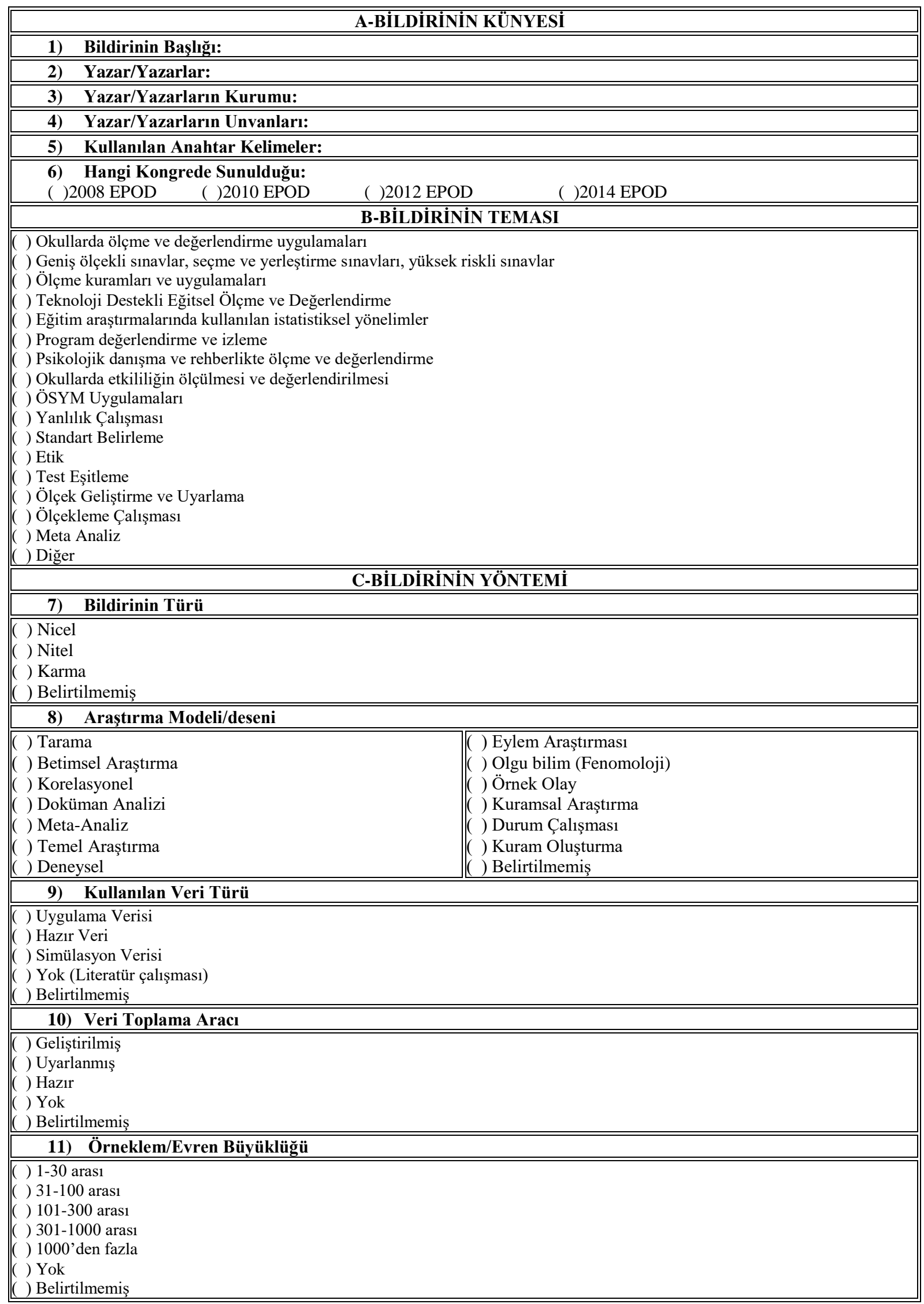

